\title{
Transactions
}

\author{
Cite this: Dalton Trans., 2012, 41, 6516
}

wWw.rsc.org/dalton

PAPER

\section{Silver(I) complexes of 9-anthracenecarboxylic acid and imidazoles: synthesis, structure and antimicrobial activity $\dagger$}

\author{
Malachy McCann, ${ }^{a}$ Robert Curran, ${ }^{a}$ Marcia Ben-Shoshan, ${ }^{a}$ Vickie McKee, ${ }^{* b}$ Asif Ali Tahir, ${ }^{b}$ \\ Michael Devereux, ${ }^{c}$ Kevin Kavanagh, ${ }^{d}$ Bernadette S. Creaven ${ }^{e}$ and Andrew Kellett ${ }^{f}$
}

Received 12th November 2011, Accepted 16th March 2012

DOI: $10.1039 / \mathrm{c} 2 \mathrm{dt12166b}$

$\left[\mathrm{Ag}_{2}(9-\mathrm{aca})_{2}\right](\mathbf{1})(9$-acaH $=9$-anthracenecarboxylic acid $)$ reacts with a series of imidazoles to give $\left[\mathrm{Ag}(\mathrm{imidH})_{2.3}\left(\mathrm{CH}_{3} \mathrm{CN}\right)_{0.7}\right](9$-aca $)(3),\left[\mathrm{Ag}_{6}(\mathrm{imidH})_{4}(9 \text {-aca })_{6}(\mathrm{MeOH})_{2}\right](4),\left\{\left[\mathrm{Ag}(1-\mathrm{Me}-\mathrm{imid})_{2}\right]_{2}\left[\mathrm{Ag}_{4}(9-\right.\right.$ aca $\left.\left.)_{6}\right]\right\}(5),\left\{\left[\mathrm{Ag}(1-\mathrm{Bu}-\mathrm{imid})_{2}\right]_{2}\left[\mathrm{Ag}_{4}(9-\mathrm{aca})_{6}\right]\right\}(6)$ and $[\mathrm{Ag}(\mathrm{apim})](9-\mathrm{aca}) \cdot \mathrm{H}_{2} \mathrm{O}(7)$ (imidH $=$ imidazole; 1-Me-imid =1-methylimidazole; 1 -Bu-imid = 1-butylimidazole; apim =1-(3-aminopropyl)imidazole) . The mononuclear complex $\mathbf{3}$, hexanuclear 4-6, and polymeric $\mathbf{7}$, were all characterised using X-ray crystallography. While many of the complexes possess excellent in vitro antifungal and antibacterial activities they are, unanimously, more effective against fungal cells. The insect, Galleria mellonella, can survive high doses of the $\mathrm{Ag}(\mathrm{I})$ complexes administered in vivo, and a number of the complexes offer significant protection to larvae infected with a lethal dose of pathogenic Candida albicans cells.

\section{Introduction}

Pathogenic fungi and bacteria cause many infectious diseases in both immunosuppressed and immunocompetent individuals. Additionally, infections with resistant microorganisms are often associated with high rates of morbidity and mortality and also increase health care treatment costs. ${ }^{1-4}$ In recent times, there has been something of a renaissance in the use of nanoparticulate silver(0) and silver(I) complexes to prevent and to treat stubborn microbial infections. Despite the fact that microbial resistance to $\mathrm{Ag}(\mathrm{I})$ is relatively rare, $\mathrm{Ag}(\mathrm{I})$-resistance genes have been identified, giving rise to concerns over the widespread use of clinical and hygiene products containing silver. ${ }^{5}$ Although a small number of people experience delayed sensitivity to silver, the

\footnotetext{
${ }^{a}$ Department of Chemistry, National University of Ireland, Maynooth, Co. Kildare, Ireland

${ }^{b}$ Chemistry Department, Loughborough University, Loughborough, Leics., LE11 3TU, UK.E-mail:v.mckee@lboro.ac.uk

${ }^{c}$ The Inorganic Pharmaceutical and Biomimetic Research Laboratory, Focas Institute, Dublin Institute of Technology, Kevin St., Dublin 2, Ireland

${ }^{d}$ Department of Biology, National University of Ireland, Maynooth, Co. Kildare, Ireland

${ }^{e}$ Centre of Applied Science for Health, Institute of Technology Tallaght, Dublin, Dublin 24, Ireland

${ }^{f}$ School of Chemical Sciences and National Institute for Cellular Biotechnology, Dublin City University, Glasnevin, Dublin 9, Ireland $\dagger$ Electronic supplementary information (ESI) available. CCDC reference numbers 782886-782890 (X-ray supplementary data for [Ag(imidH) $\left.)_{2.3}\left(\mathrm{CH}_{3} \mathrm{CN}\right)_{0.7}\right]\left(9\right.$-aca) (3), $\left[\mathrm{Ag}_{6}(\mathrm{imidH})_{4}(9 \text {-aca })_{6}(\mathrm{MeOH})_{2}\right]$ (4), $\left\{\left[\mathrm{Ag}(1-\mathrm{Me}-\mathrm{imid})_{2}\right]_{2}\left[\mathrm{Ag}_{4}(9-\mathrm{aca})_{6}\right]\right\} \quad(5), \quad\left\{\left[\mathrm{Ag}(1-\mathrm{Bu} \text {-imid })_{2}\right]_{2}\left[\mathrm{Ag}_{4}(9-\right.\right.$ aca $\left.\left.)_{6}\right]\right\}$ (6) and $[\mathrm{Ag}($ apim $)](9-\mathrm{aca}) \cdot \mathrm{H}_{2} \mathrm{O}(7)$ ). For ESI and crystallographic data in CIF or other electronic format see DOI: 10.1039/ c2dt12166b
}

metal and its monocation do not present a serious toxic risk to any organ system in the human body. ${ }^{6}$

The $\operatorname{Ag}(\mathrm{I})$ ion is now the active agent in many healthcare products such as silver-coated catheters, ${ }^{7}$ wound dressings ${ }^{8,9}$ and burn treatment creams. ${ }^{10}$ Evidence has been provided ${ }^{11}$ for the antifungal activity of a burn wound dressing coated with $\mathrm{AgNO}_{3}$ against Candida albicans, C. glabrata, C. tropicalis and Saccharomyces cerevisiae. $\operatorname{Ag}(0)$ nanoparticles have been incorporated into a topical antimicrobial gel and demonstrated potent activity against Aspergillus niger and C. albicans. ${ }^{12}$ The antimicrobial effects of medical devices containing $\operatorname{Ag}(0)$ have formed the basis of a recent review which highlights the growing importance of materials that prevent microbial surface adhesion. ${ }^{13}$

$\operatorname{The} \mathrm{Ag}(\mathrm{I})$ ion is known to interfere with electron transport ${ }^{14}$ and alter the respiration of C. albicans cells. ${ }^{15} \mathrm{McCann}$ and coworkers suggested that the interaction of $\operatorname{Ag}(\mathrm{I})$ and the mitochondrion, ${ }^{14-16}$ coupled with the generation of lipid peroxides, ${ }^{14}$ was evidence for the generation of free radicals. More recently, ${ }^{17}$ it has been demonstrated that C. albicans cells respond to $\mathrm{AgClO}_{4}$ by activating an oxidative stress response via phosphorylation of a high osmolarity protein (Hog1P) and nuclear translocation of the C. albicans activating protein-1 (Cap1p). The high antimicrobial efficacy of tetrahedral, Ag(I) bis-phosphine ${ }^{18}$ and $N$-heterocyclic carbene ${ }^{19}$ complexes has been demonstrated. $\mathrm{Li}$ and coworkers ${ }^{20}$ reported that the hexanuclear $\mathrm{Ag}(\mathrm{I})$ complex, $\left[\mathrm{Ag}_{6} \mathrm{~L}_{6}\right] \cdot 4 \mathrm{DMF}$ ( $\mathrm{HL}=2$-thiophene $N(4)$ methylthiosemicarbazone), showed moderate activity against Gram negative and Gram positive bacteria with $\mathrm{MIC}_{100}$ values (minimum inhibitory concentration of complex required for $100 \%$ retardation of bacterial cell growth) $\geq 0.5 \mu \mathrm{g} \mathrm{cm}^{-3}$ and displayed poor growth inhibition towards the fungi, C. albicans and C. lusitaniae. In recent studies, $\left[\mathrm{Ag}_{2}(\text { phen })_{3}(\mathrm{mal})\right] \cdot 2 \mathrm{H}_{2} \mathrm{O}$ (phen 
= 1,10-phenanthroline; malH $_{2}=$ malonic acid) was shown to inhibit the growth of $C$. albicans, by affecting mitochondrial function, retarding cytochrome synthesis, uncoupling cellular respiration and causing gross distortions in cell morphology. ${ }^{21}$ The mononuclear complex, $\left[\mathrm{Ag}(\text { phendio })_{2}\right] \mathrm{ClO}_{4}$ (phendio $=$ 1,10-phenanthroline-5,6-dione), strongly inhibited the growth of C. albicans and caused extensive, non-specific DNA cleavage in the organism. ${ }^{22}$ Against the same fungi, the Ag(I) salicylate complexes, $\left[\mathrm{Ag}_{2}(\mathrm{salH})_{2}\right]$ and $\left[\mathrm{Ag}_{2}\left(\mathrm{NH}_{3}\right)_{2}(\mathrm{salH})_{2}\right]\left(\mathrm{salH}_{2}=\right.$ salicylic acid), had $\mathrm{MIC}_{100}$ values of 5.0 and $0.5 \mu \mathrm{M}$, respectively. ${ }^{23}$

Investigations into the effects of silver(I) ions on bacterial cells revealed that they interact with the respiratory chain of Escherichia coli $^{24}$ and can lower the content of phospholipid fatty acids in some metal-reducing bacteria. ${ }^{25}$ Electron microscopy and X-ray microanalysis have shown that silver builds up as granules in the cell wall and in the cytoplasm of E. coli and Staphylococcus aureus, ${ }^{26,27}$ inflicting damage to the RNA and DNA and also deactivating cellular proteins. The most widely known bactericidal mechanism of the $\operatorname{Ag}(\mathrm{I})$ ion is its interaction with the thiol group of the L-cysteine residue of proteins and consequent enzyme inactivation. ${ }^{28-30}$ Other $\mathrm{Ag}(\mathrm{I}) \mathrm{bac}-$ tericidal mechanisms, such as $\mathrm{K}^{+}$ion release, ${ }^{31}$ bonding to $\mathrm{DNA}^{32}$ and the generation of intracellular reactive oxygen species, ${ }^{24,33,34}$ have also been reported.

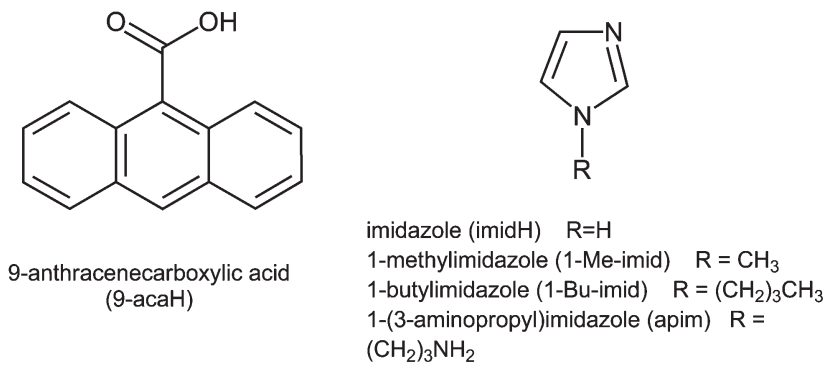

Fig. 1 Ligand structures.
In 2007, we reported ${ }^{35}$ the structures and biological activities of dinuclear and tetranuclear Ag(I) complexes containing the 9anthracenecarboxylate anion $(9$-acaH $=9$-anthracenecarboxylic acid (Fig. 1)). $\left[\operatorname{Ag}_{2}(9 \text {-aca })_{2}\right]$ (1) was found to be very active against the bacterial species $E$. coli and methicillin-resistant S. aureus (MRSA) $\left(\mathrm{MIC}_{50}=22.44\right.$ and $11.36 \mu \mathrm{M}$, respectively) and against the fungus $C$. albicans $\left(\mathrm{MIC}_{100}=0.95 \mu \mathrm{M}\right)$. However, the tetranuclear, amine complex, $\left[\mathrm{Ag}_{4}(9-\mathrm{aca})_{4}\left(\mathrm{NH}_{3}\right)_{2}\right]$ (2), displayed enhanced activity universally against the microbial cells (corresponding inhibitory concentrations were 8.51, 5.44 and $0.14 \mu \mathrm{M}$, respectively). ${ }^{35}$ The significant improvement in biological activity witnessed upon the introduction of the $\mathrm{NH}_{3}$ ligands in 2 and in $\left[\mathrm{Ag}_{2}\left(\mathrm{NH}_{3}\right)_{2}(\mathrm{salH})_{2}\right]^{23}$ was the stimulus for the present work.

Herein, we report the synthesis, structures and in vitro antimicrobial effects of a series of new $\mathrm{Ag}(\mathrm{I})$ complexes containing both the $9-\mathrm{aca}^{-}$anion and $\mathrm{N}$-donor ligands based on imidazole (Fig. 1). Metal complexes containing imidazole-based ligands are also of interest because the imidazole ring is an essential metal binding site in many metalloproteins. In addition to measuring the in vitro antimicrobial properties of the present Ag(I) complexes their in vivo cytotoxicities were also examined using the insect model, Galleria mellonella.

\section{Experimental}

Infrared spectra were recorded in the region $4000-370 \mathrm{~cm}^{-1}$ on a Perkin Elmer System 2000 FT spectrometer. Microanalytical data were provided by the Microanalytical Laboratory, University College Dublin, Belfield, Dublin 4, Ireland. X-ray crystallographic data (Table 1) were collected at 150(2) K on a Bruker APEX II diffractometer and the structures were solved by direct methods and refined on $F^{2}$ using all the reflections. ${ }^{36}$ All of the non-hydrogen atoms were refined using anisotropic atomic displacement parameters. Hydrogen atoms were inserted at

Table 1 Crystallographic data for complexes 3-7

\begin{tabular}{|c|c|c|c|c|c|}
\hline Complex & 3 & 4 & 5 & 6 & 7 \\
\hline Formula & $\mathrm{C}_{23.30} \mathrm{H}_{20.3} \mathrm{Ag} \mathrm{N} \mathrm{N}_{5.3} \mathrm{O}_{2}$ & $\mathrm{C}_{104} \mathrm{H}_{78} \mathrm{Ag}_{6} \mathrm{~N}_{8} \mathrm{O}_{14}$ & $\mathrm{C}_{106} \mathrm{H}_{78} \mathrm{Ag}_{6} \mathrm{~N}_{8} \mathrm{O}_{12}$ & $\mathrm{C}_{118} \mathrm{H}_{102} \mathrm{Ag}_{6} \mathrm{~N}_{8} \mathrm{O}_{12}$ & $\mathrm{C}_{21} \mathrm{H}_{22} \mathrm{AgN}_{3} \mathrm{O}_{3}$ \\
\hline Formula weight & 514.42 & 2310.96 & 2302.98 & 2471.30 & 472.29 \\
\hline Crystal size, $\mathrm{mm}^{3}$ & $0.33 \times 0.22 \times 0.21$ & $0.23 \times 0.15 \times 0.12$ & $0.43 \times 0.32 \times 0.06$ & $0.32 \times 0.19 \times 0.12$ & $0.20 \times 0.17 \times 0.07$ \\
\hline Crystal system & Monoclinic & Orthorhombic & Triclinic & Triclinic & Orthorhombic \\
\hline Space group & $P 2_{1} / n$ & Pbcn & $P \overline{1}$ & $P \overline{1}$ & Pbca \\
\hline$a, \AA$ & $9.7905(5)$ & $20.6935(8)$ & $11.7251(17)$ & $17.6333(7)$ & $9.6450(6)$ \\
\hline$b, \AA$ & $14.2012(7)$ & $18.2786(7)$ & $17.908(3)$ & $19.3853(8)$ & $19.0589(11)$ \\
\hline$c, \AA$ & $16.3251(9)$ & $23.6859(10)$ & $23.464(3)$ & $30.4753(13)$ & $21.2920(12)$ \\
\hline$\alpha,^{\circ}$ & 90 & 90 & $111.403(2)$ & $96.019(1)$ & 90 \\
\hline$\beta,^{\circ}$ & $101.864(1)$ & 90 & $90.095(2)$ & $95.831(1)$ & 90 \\
\hline$\gamma, \circ$ & 90 & 90 & $101.710(2)$ & $90.237(1)$ & 90 \\
\hline$V, \AA^{3}$ & $2221.3(2)$ & $8959.1(6)$ & $4476.2(11)$ & $10305.1(7)$ & $3914.0(4)$ \\
\hline Z & 4 & 4 & 2 & 4 & 8 \\
\hline$D_{\mathrm{c}}, \mathrm{Mg} \mathrm{m}^{-3}$ & 1.538 & 1.713 & 1.709 & 1.593 & 1.603 \\
\hline$\mu, \mathrm{mm}^{-1}$ & 0.938 & 1.358 & 1.357 & 1.185 & 1.057 \\
\hline Refl collected & 19005 & 80667 & 35083 & 89958 & 37907 \\
\hline Refl unique $\left(R_{\text {int }}\right)$ & $4361(0.0326)$ & $9793(0.0580)$ & $15686(0.0421)$ & $40407(0.0422)$ & $4890(0.0398)$ \\
\hline Data/restraints/parameters & $4361 / 23 / 326$ & $9793 / 0 / 599$ & $15686 / 0 / 1194$ & $40407 / 3021 / 2665$ & $4890 / 6 / 265$ \\
\hline Goodness-of-fit on $F^{2}$ & 1.049 & 1.025 & 1.049 & 1.067 & 1.027 \\
\hline$R_{1}, \mathrm{w} R_{2}[I>2 \sigma(I)]$ & $0.0347,0.0730$ & $0.0316,0.0695$ & $0.0666,0.1746$ & $0.0505,0.1130$ & $0.0280,0.0665$ \\
\hline$R_{1}, \mathrm{w} R_{2}$ (all data) & $0.0460,0.0782$ & $0.0475,0.0765$ & 0.08560 .1882 & $0.0739,0.1228$ & $0.0410,0.0723$ \\
\hline$\Delta \rho_{\min }, \Delta \rho_{\max }$, e $\AA^{-3}$ & $0.936,-1.192$ & $0.487,-0.788$ & $4.988,-1.066$ & $1.703,-0.978$ & $0.447,-0.546$ \\
\hline
\end{tabular}


calculated positions using a riding model, except for those bonded to oxygen or nitrogen in complex 7, which were located from difference maps and the coordinates refined. When the refinement for complex $\mathbf{5}$ had converged there remained a number of peaks in the electron density map at $c a .5 \mathrm{e} \AA^{-3}$, and a second crystal showed the same effect. The geometry of these peaks was similar to the arrangement of silver ions in the main components, and it seems likely that these effects are due to a small twin contribution. However, attempts to incorporate this did not improve the model. In complex 6 there are two independent $\left\{\left[\mathrm{Ag}(1-\mathrm{Bu} \text {-imid })_{2}\right]_{2}\left[\mathrm{Ag}_{4}(9 \text {-aca })_{6}\right]\right\}$ assemblies in the asymmetric unit, oriented about $90^{\circ}$ to each other and very similar to one another. There is a disorder in the alkyl substituents attached to four of the eight imidazole groups and these were each modelled with partial occupancy of two overlapping sites $(50: 50$ or 60 : 40). Some restraints (SAME and ISOR) were also employed.

Sterilisation of microbiological equipment and media was carried out at $394 \mathrm{~K}$ and $124 \mathrm{kPa}$ for $20 \mathrm{~min}$. Solutions that were susceptible to decomposition during autoclaving were sterilised by membrane filtration using $0.45 \mu \mathrm{m}$ Millipore membrane filters. All worktops and benches were sterilised by washing with $70 \%(\mathrm{v} / \mathrm{v})$ ethanol-water prior to use. Round-bottomed microtitre plates were read using a Labsystems iEMS Reader MF at $540 \mathrm{~nm}$ (C. albicans). Flat-bottomed microtitre plates were read using a Bio-Tek Synergy HT plate reader at $600 \mathrm{~nm}$ (E. coli and MRSA). Fungal cell density was measured using a Neubauer hemocytometer under a light microscope at a magnification of $\times 400$. Bacterial cell density was recorded at an optical density of $600 \mathrm{~nm}$ using an Eppendorf Biophotometer.

Chemicals were purchased from commercial sources and were used without further purification. All of the silver(I) complexes were synthesised in the absence of light and the products were stored in the dark. $\left[\mathrm{Ag}_{4}(9 \text {-aca })_{4}\left(\mathrm{NH}_{3}\right)_{2}\right]$ (2) was prepared from $\left[\operatorname{Ag}_{2}(9-\mathrm{aca})_{2}\right](\mathbf{1})$ in accordance with the literature method. ${ }^{35}$ C. albicans ATCC 10231 was obtained from the American Type Culture Collection, Manassas, VA, USA. E. coli was supplied as a clinical isolate by the Clinical Microbiology Laboratory, St. James's Hospital, Dublin, Ireland, and was originally isolated from a wound infection. MRSA was obtained as a clinical isolate from Microbiologics, North St. Cloud Mn, USA, and was originally isolated from a wound infection. G. mellonella larvae in the sixth developmental stage were obtained from Livefoods Direct Ltd., Sheffield, S25 4JJ, UK. They were stored at $288 \mathrm{~K}$ in wood shavings and used within 3 weeks of delivery. Significance of the larvae survival rates was analysed at $72 \mathrm{~h}$ using the log rank (Mantel-Cox) method utilising GraphPad Prism software (version 5). Three categories of significance were used $(*=p<0.05, * *=p<0.01$ and $* * *=p<0.001)$.

\section{Preparation of $\left[\mathrm{Ag}_{2}(9-\mathrm{aca})_{2}\right](1)$}

This complex was prepared using an improved modification of the literature procedure. ${ }^{35}$ 9-Anthracenecarboxylic acid (9-acaH) $(1.117 \mathrm{~g}, 5.03 \mathrm{mmol})$ was added slowly to a solution of potassium hydroxide $(0.282 \mathrm{~g}, 5.03 \mathrm{mmol})$ in water $\left(30 \mathrm{~cm}^{3}\right)$ until $\mathrm{pH} 7$ was reached. The solution was then filtered to remove any undissolved material. A solution of silver nitrate $(0.849 \mathrm{~g}$, $5.03 \mathrm{mmol})$ in water $\left(10 \mathrm{~cm}^{3}\right)$ was added dropwise to the
$\mathrm{K}^{+}(9 \text {-aca })^{-}$solution. The resulting suspension was stirred for $0.5 \mathrm{~h}$ and then filtered. The yellow solid was washed with ethanol and air-dried. Yield: $1.202 \mathrm{~g}(73 \%)$.

\section{Preparation of crystalline $\left[\mathrm{Ag}(\mathrm{imidH})_{2.3}\left(\mathrm{CH}_{3} \mathrm{CN}\right)_{0.7}\right](9$-aca) (3)}

$\left[\mathrm{Ag}_{2}(9-\mathrm{aca})_{2}\right](\mathbf{1})(0.329 \mathrm{~g}, 0.5 \mathrm{mmol})$ was stirred in hot acetonitrile $\left(70 \mathrm{~cm}^{3}\right)$ and any small traces of undissolved material was removed by filtration. Imidazole $(0.207 \mathrm{~g}, 3.0 \mathrm{mmol})$ was dissolved in acetonitrile $\left(10 \mathrm{~cm}^{3}\right)$ and added slowly to the stirred solution of 1 . The small amount of white precipitate which formed was filtered off and the clear filtrate was allowed to stand overnight. The white crystalline product which formed was filtered off, washed with acetonitrile and air-dried. Yield: $0.09 \mathrm{~g}$ (18\%). Solubility: soluble in $\mathrm{MeOH}$, hot $\mathrm{EtOH}$ and DMSO. Anal. calcd for $\mathrm{C}_{23.30} \mathrm{H}_{20.30} \mathrm{AgN}_{5.30} \mathrm{O}_{2}: \mathrm{C}, 54.40 ; \mathrm{H}, 3.98$; $\mathrm{N}, 14.43 \%$. Found: C, 54.15; H, 3.91; N, 14.61\%. IR $\left(\mathrm{cm}^{-1}\right.$, $\mathrm{KBr})$ : 3436, 3128, 3030, 2923, 2837, 2700, 2624, 2250, 1625, 1562, 1448, 1426, 1390, 1320, 1275, 1261, 1072.

\section{Preparation of crystalline $\left[\mathrm{Ag}_{6}(\mathrm{imidH})_{4}(9-\mathrm{aca})_{6}(\mathrm{MeOH})_{2}\right](4)$}

$\left[\mathrm{Ag}_{2}(9-\mathrm{aca})_{2}\right](\mathbf{1})(0.109 \mathrm{~g}, 0.16 \mathrm{mmol})$ was suspended in methanol $\left(10 \mathrm{~cm}^{3}\right)$ and to this was added a methanolic solution of imidazole $\left(1 \mathrm{~cm}^{3}, 0.16 \mathrm{M}, 0.16 \mathrm{mmol}\right)$. The mixture was stirred for $1 \mathrm{~h}$ and then filtered. Diethyl ether was slowly added to the filtrate to precipitate the pale-yellow product. The solid was filtered off, washed with diethyl ether and air-dried. Crystals of the product formed in the ether filtrate. Yield: $0.04 \mathrm{~g}(44 \%)$. Solubility: soluble in $\mathrm{MeOH}$ and DMSO. Anal. calcd for $\mathrm{C}_{104} \mathrm{H}_{78} \mathrm{Ag}_{6} \mathrm{~N}_{8} \mathrm{O}_{14}$ : C, 54.05; H, 3.40; N, 4.85\%. Found: C, 53.75; H, 3.39; N, 4.73\%. IR ( $\left.\mathrm{cm}^{-1}, \mathrm{KBr}\right): 3448,3045,1625$, 1538, 1484, 1433, 1393, 1320, 1273, 1238, 1178, 1090.

\section{Preparation of crystalline $\left\{\left[\mathrm{Ag}(1-\mathrm{Me}-\mathrm{imid})_{2}\right]_{2}\left[\mathrm{Ag}_{4}(\mathbf{9} \text {-aca })_{6}\right]\right\}(5)$}

1-Methylimidazole $(0.82 \mathrm{~g}, 1.0 \mathrm{mmol})$ was added to a hot suspension of $\left[\mathrm{Ag}_{2}(9-\mathrm{aca})_{2}\right]$ (1) $(0.165 \mathrm{~g}, 0.25 \mathrm{mmol})$ in ethanol $\left(30 \mathrm{~cm}^{3}\right)$ and the mixture immediately turned clear. Following filtration to remove any insoluble particles the filtrate was reduced to low volume by rotary evaporation. Diethyl ether was added to precipitate the beige solid, which was filtered off, washed with diethyl ether and allowed to air-dry. The solid was dissolved in DMSO and the solution reduced under high vacuum to yield the beige product. The solid was washed with a small amount of cold EtOH and air dried. The solid was again dissolved in the minimum volume of DMSO and crystals formed when the solution was allowed to stand for one week. Yield: $0.075 \mathrm{~g}$ (37\%). Solubility: soluble in hot $\mathrm{MeOH}, \mathrm{EtOH}$ and DMSO. Anal. calcd for $\mathrm{C}_{106} \mathrm{H}_{78} \mathrm{Ag}_{6} \mathrm{~N}_{8} \mathrm{O}_{12}$ : C, 55.27; H, 3.42; $\mathrm{N}, 4.87 \%$. Found: C, 54.98; H, 3.42; N, 4.63\%. IR ( $\left.\mathrm{cm}^{-1}, \mathrm{KBr}\right)$ : $3468,3116,1621,1565,1536,1428,1392,1321,1275,1235$, 1180, 1112, 1087, 1017.

\section{Preparation of crystalline $\left\{\left[\mathrm{Ag}(1-\mathrm{Bu} \text {-imid })_{2}\right]_{2}\left[\mathrm{Ag}_{4}(9-\mathrm{aca})_{6}\right]\right\}(6)$}

$\left[\mathrm{Ag}_{2}(9 \text {-aca })_{2}\right]$ (1) $(0.750 \mathrm{~g}, 1.14 \mathrm{mmol})$ was dissolved in hot acetonitrile $\left(80 \mathrm{~cm}^{3}\right)$ and the solution filtered to remove any 
traces of undissolved solid. The filtrate was allowed to cool to room temperature. 1-Butylimidazole $(0.567 \mathrm{~g}, 4.56 \mathrm{mmol})$ was added and the resulting solution was stirred at room temperature for $20 \mathrm{~h}$. After gravity filtration the filtrate was reduced to a low volume on a rotary evaporator and then diethyl ether was slowly added. The precipitated beige solid was filtered off, washed with diethyl ether and allowed to air-dry. The solid was recrystallised from hot ethanol to yield yellow crystals, which were then filtered off, washed with cold ethanol $\left(1 \mathrm{~cm}^{3}\right)$ and allowed to airdry. Yield: $0.301 \mathrm{~g}$ (51\%). Solubility: soluble in $\mathrm{MeOH}$, hot EtOH, $\mathrm{CHCl}_{3}$ and DMSO. Anal. calcd for $\mathrm{C}_{118} \mathrm{H}_{102} \mathrm{Ag}_{6} \mathrm{~N}_{8} \mathrm{O}_{12}$ : C, 57.35; H, 4.16; N, 4.53\%. Found: C, 57.23; H, 4.23; N, $4.47 \%$. IR ( $\left.\mathrm{cm}^{-1}, \mathrm{KBr}\right): 3468,2958,1622,1565,1536,1427$, $1391,1321,1274,1232,1179,1112,1085,1018$.

\section{Preparation of crystalline $[\mathrm{Ag}(\operatorname{apim})](9-\mathrm{aca}) \cdot \mathrm{H}_{2} \mathrm{O}$ (7)}

$\left[\mathrm{Ag}_{2}(9-\mathrm{aca})_{2}\right]$ (1) $(0.500 \mathrm{~g}, 0.76 \mathrm{mmol})$ was dissolved in hot acetonitrile $\left(70 \mathrm{~cm}^{3}\right)$ and the solution filtered to remove any undissolved particles. 1-(3-Aminopropyl)imidazole $(0.190 \mathrm{~g}$, $1.52 \mathrm{mmol})$ was dissolved in acetonitrile $\left(5 \mathrm{~cm}^{3}\right)$ and added to the stirred solution of $\mathbf{1}$. The resulting suspension was stirred for $0.5 \mathrm{~h}$ at room temperature and the beige solid was filtered off, washed with acetonitrile and air-dried. The solid was recrystallised from a 9:1 ethanol-methanol mixture to yield colourless crystals. Yield: $0.589 \mathrm{~g}(82 \%)$. Solubility: soluble in $\mathrm{MeOH}$, hot EtOH and DMSO. Anal. calcd for $\mathrm{C}_{21} \mathrm{H}_{22} \mathrm{AgN}_{3} \mathrm{O}_{3}: \mathrm{C}, 53.40 ; \mathrm{H}$, $4.70 \%$; N, 8.90\%. Found: C, 53.31; H, 4.58\%; N, 8.89\%. IR $\left(\mathrm{cm}^{-1}, \mathrm{KBr}\right): 3427,3236,3129,3046,2932,1568,1518,1425$, 1389, 1319, 1277, 1231, 1112, 1089, 1055.

In vitro antimicrobial screening. Minimal growth media (MM) was prepared as previously described. ${ }^{35}$ Yeast extract peptone dextrose (YEPD) media was composed of $2 \%(\mathrm{w} / \mathrm{v})$ glucose, $2 \%(\mathrm{w} / \mathrm{v})$ bacteriological peptone and $1 \%(\mathrm{w} / \mathrm{v})$ yeast extract. To solidify the media $2 \%(\mathrm{w} / \mathrm{v})$ bacteriological agar was added when required. Nutrient broth and phosphate buffered saline (PBS) were made up according to the manufacturer's instructions (Scharlau Microbiology and Aldrich, respectively).

In vitro bacterial susceptibility testing. E. coli and methicillinresistant $S$. aureus (MRSA) were grown on nutrient broth agar plates at $310 \mathrm{~K}$ and maintained at $277 \mathrm{~K}$ for short-term storage. All assays were run in triplicate and on three independent occasions. Fresh solutions of complexes were prepared immediately prior to testing. Complexes $(0.020 \mathrm{~g})$ were added to DMSO $\left(1 \mathrm{~cm}^{3}\right)$ then water $\left(9 \mathrm{~cm}^{3}\right)$ was added to give a stock solution (concentration $2000 \mathrm{mg} \mathrm{cm}^{-3}$ ). Complexes with low solubility were tested as fine suspensions. The stock solution $\left(1 \mathrm{~cm}^{3}\right)$ was added to water $\left(9 \mathrm{~cm}^{3}\right)$ to yield a solution/suspension with a concentration of $200 \mu \mathrm{g} \mathrm{cm}^{-3}$.

Nutrient broth $(100 \mu \mathrm{l})$ was added to each well of a 96-well, flat-bottomed microtitre plate. Water $(100 \mu \mathrm{l})$ was added to column 1 of the plate (negative control with no bacterial cells). Column 2 was the positive control (media with bacterial cells). $100 \mu \mathrm{l}$ of the above complex solution $\left(200 \mu \mathrm{g} \mathrm{cm}^{-3}\right)$ was added to every well in column 3 . Serial dilutions $(1: 1)$ were made from column 3-12 to produce a test concentration range of $100-0.2 \mu \mathrm{g} \mathrm{cm}{ }^{-3}$.
E. coli and MRSA were grown overnight to the stationary phase in nutrient broth at $310 \mathrm{~K}$ and $200 \mathrm{rpm}$. The cells were diluted to give an optical density of 0.1 at $\lambda=600 \mathrm{~nm}$. The cell suspension $(100 \mu \mathrm{l})$ was added to every well in columns $2-12$. The completed plates were incubated at $310 \mathrm{~K}$ in a static incubator and the final optical density recorded. $\mathrm{MIC}_{50}$ values (minimum concentration required to inhibit $50 \%$ of cell growth) were then determined and expressed in terms of $\mu \mathrm{M}$ concentration.

In vitro fungal susceptibility testing. $C$. albicans (ATCC 10231) was grown on YEPD agar plates at $310 \mathrm{~K}$ and maintained at $277 \mathrm{~K}$ for short-term storage. All assays were run in triplicate and on three independent occasions. Fresh solutions of complexes were prepared immediately prior to testing. Complexes $(0.020 \mathrm{~g})$ were dissolved in DMSO $\left(1 \mathrm{~cm}^{3}\right)$ and added to water $\left(9 \mathrm{~cm}^{3}\right)$ to give a stock solution (concentration $2000 \mathrm{mg}$ $\mathrm{cm}^{-3}$ ). Complexes with low solubility were tested as fine suspensions. The stock solution (or suspension) $\left(0.5 \mathrm{~cm}^{3}\right)$ was added to water $\left(9.5 \mathrm{~cm}^{3}\right)$ to give a solution with a concentration of $100 \mu \mathrm{g}$ $\mathrm{cm}^{-3}$. MM (100 $\left.\mu \mathrm{l}\right)$ was added to each well of a 96-well, roundbottomed microtitre plate. Water $(100 \mu \mathrm{l})$ was added to column 1 of the plate (negative control, media with no fungal cells). Column 2 was the positive control (media and fungal cells only). $100 \mu \mathrm{l}$ of the above complex solution $\left(100 \mu \mathrm{g} \mathrm{cm}^{-3}\right)$ was added to every well in column 3 . Serial dilutions $(1: 1)$ were made from columns $3-12$ to produce a test concentration range of $50-0.1 \mu \mathrm{g} \mathrm{cm}^{-3}$.

C. albicans was grown to the stationary phase overnight at $310 \mathrm{~K}$ on YEPD media. The cells were washed with PBS solution and resuspended in MM at a density of $5 \times 10^{5}$ cells $\mathrm{cm}^{-3}$. The cell suspension $(100 \mu \mathrm{l})$ was added to every well in columns 2-12. The completed plate was then covered with acetate foil (Sarstedt) to prevent dehydration. The plate was incubated at $310 \mathrm{~K}$ with continuous shaking for $24 \mathrm{~h}$. The optical density $(\lambda=540 \mathrm{~nm})$ of each well was recorded at $1 \mathrm{~h}$ intervals. $\mathrm{MIC}_{100}$ values were then determined and expressed in terms of $\mu \mathrm{M}$ concentration.

In vivo cytotoxicity studies using Galleria mellonella. Since the immune system of insects bears a number of strong structural and functional similarities to the innate immune system of mammals, ${ }^{37,38}$ insects can be used to screen the in vivo effect of drugs without the necessity of mammalian testing. The larvae of the greater wax moth, G. mellonella, have been utilised successfully since 1982 for in vivo studies of the pathogenicity of bacteria and fungi. ${ }^{39-43}$ With specific reference to C. albicans, the G. mellonella model has provided invaluable information from fungal virulence studies. ${ }^{44-48}$ Furthermore, the curative effects of antifungal prescription drugs ${ }^{49}$ and some silver(I) compounds ${ }^{50}$ on $C$. albicans-infected $G$. mellonella have already been determined.

G. mellonella larvae in the sixth developmental stage were used to determine the in vivo cytotoxicity of ketoconazole, $\mathrm{AgNO}_{3}$ and complexes 1-7. Ten healthy larvae, between $0.20-0.40 \mathrm{~g}$ in weight and with no cuticle discoloration, were used in each test. Fresh solutions of the test complexes were prepared immediately prior to testing. Test compounds $(0.020 \mathrm{~g})$ were dissolved in DMSO $\left(1 \mathrm{~cm}^{3}\right)$ and added to water $\left(9 \mathrm{~cm}^{3}\right)$ to 
give a stock solution (concentration $2000 \mathrm{mg} \mathrm{cm}^{-3}$ ). Test solutions were made from this stock solution. In cases of limited solubility the resulting suspensions were used for the tests. Each compound was tested at two concentrations; $100 \mu \mathrm{g} \mathrm{cm}^{-3}$ and twice their $\mathrm{MIC}_{100}$ value (in $\left.\mu \mathrm{g} \mathrm{cm}^{-3}\right)$. The test solution $(20 \mu \mathrm{l})$ was administered to the larvae by injection directly into the haemocoel through the last pro-leg. The base of the pro-leg can be opened by applying gentle pressure to the sides of the larvae and this aperture will re-seal after removal of the syringe without leaving a scar. Larvae were placed in sterile petri dishes and incubated at $303 \mathrm{~K}$ for $72 \mathrm{~h}$. Larvae survival was monitored after this $72 \mathrm{~h}$ period. Death was assessed by the lack of movement in response to stimulus together with discoloration of the cuticle. Three controls were employed in all assays. The first consisted of untouched larvae maintained at the same temperature as the test larvae. The second was larvae with the pro-leg pierced with an inoculation needle but no substance injected into them. The third control was larvae that were inoculated with $20 \mu \mathrm{l}$ of the same sterile water used to make the test solutions.

In vivo antifungal screening using G. mellonella. G. mellonella larvae in the sixth developmental stage were used to determine the in vivo antimicrobial activity of ketoconazole, $\mathrm{AgNO}_{3}$ and complexes 1-7. As with the cytotoxicity studies (see above) ten larvae were injected with a fresh solution (or suspension) of the complex. Test concentrations were again $100 \mu \mathrm{g} \mathrm{cm}^{-3}$ and twice their $\mathrm{MIC}_{100}$ value (in $\mu \mathrm{g} \mathrm{cm}^{-3}$ ). C. albicans was grown to the stationary phase in YEPD media at $310 \mathrm{~K}$ for $24 \mathrm{~h}$. The cell concentration was assessed using a haemocytometer following dilution of the culture with PBS. The cells were washed three times with PBS and re-suspended in sterile PBS following harvesting by centrifugation $(4000 \times \mathrm{g}$ for $10 \mathrm{~min})$ to yield a suspension of $1 \times 10^{8}$ cell $\mathrm{cm}^{-3}$.

Two treatments (prophylactic and treatment of infection) were employed in the screening of the test solutions. Five controls were used in each assay. The first control consisted of untouched larvae maintained at the same temperature as the test larvae (negative control). The second was larvae with the pro-leg pierced with an inoculation needle but no substance injected into them. The third control was larvae that were inoculated with the same sterile water $(20 \mu \mathrm{l})$ used to make the test solutions, and the fourth was larvae inoculated with the same sterile PBS solution used to wash and make the $C$. albicans suspension. The positive control consisted of larvae inoculated with $C$. albicans and no test solution administered. The latter control is the one given in the results illustrated in Fig. 12. Significance was determined using the log rank (Mantel-Cox) method. Positive results were placed into one of three categories: $*=p<0.05$, $* *=p<0.01$ and $* * *=p<0.001$.

Prophylactic treatment. The test solution $(20 \mu \mathrm{l})$ was administered to the larvae by injection as outlined above. Larvae were then placed in sterile petri dishes and incubated at $303 \mathrm{~K}$ for $1 \mathrm{~h}$, after which time they were inoculated with $20 \mu \mathrm{l}$ of the C. albicans cell suspension $\left(2 \times 10^{6}\right.$ cells $)$. This number represents a lethal dose of fungal cells. The larvae were incubated at $303 \mathrm{~K}$ for $72 \mathrm{~h}$ and larvae survival was monitored immediately after this period.

Treatment of infection. Larvae were inoculated with $20 \mu \mathrm{l}$ of the $C$. albicans suspension $\left(2 \times 10^{6}\right.$ cells $)$ by injection as described above. The larvae were then placed in sterile petri dishes and incubated at $303 \mathrm{~K}$ for $1 \mathrm{~h}$, after which time the test solution $(20 \mu \mathrm{l})$ was administered by injection. The larvae were incubated at $303 \mathrm{~K}$ for $72 \mathrm{~h}$ and larvae survival was monitored immediately after this period.

\section{Results and discussion}

\section{Complex syntheses and structures}

Synthetic routes to the complexes are given in Scheme 1. Our previously reported synthesis of $\left[\mathrm{Ag}_{2}(9-\mathrm{aca})_{2}\right]$ (1), from $\mathrm{Ag}_{2} \mathrm{O}$ and $9-\mathrm{acaH},{ }^{35}$ had the major drawback of a low product yield $(21 \%)$. A greatly improved yield $(73 \%)$ was achieved by reacting the salt, $\mathrm{K}^{+}(9-\mathrm{aca})^{-}$, with $\mathrm{AgNO}_{3}$. The complex consists of polymeric ribbons of linked disilver(I), syn-syn bridged, dicarboxylate units and having an $\mathrm{Ag}-\mathrm{Ag}$ distance of 2.851(1) $\AA^{35}$ Complex 1 was used as the starting material for the preparation of the other silver(I) complexes. The previously reported complex, $\left[\mathrm{Ag}_{4}(9 \text {-aca })_{4}\left(\mathrm{NH}_{3}\right)_{2}\right](\mathbf{2}),{ }^{35}$ was prepared by reacting $\mathbf{1}$ with aqueous ammonia. Complex 2 was shown to be tetrameric and centrosymmetric, with two syn-syn bridging carboxylates linked to the bimetallic $\mathrm{Ag}-\mathrm{Ag}$ core, and a further two, syn-anti bridged carboxylate ligands in the equatorial plane, being coordinated to one $\mathrm{Ag}$ in the bimetallic core and to a second $\mathrm{Ag}$, with the latter also bonded to an $\mathrm{NH}_{3}$ ligand. The closest $\mathrm{Ag}-\mathrm{Ag}$ distance in the complex is 2.939(1) $\AA$.

The imidazole complex, $\left[\mathrm{Ag}(\mathrm{imidH})_{2.3}\left(\mathrm{CH}_{3} \mathrm{CN}\right)_{0.7}\right](9$-aca $)$ (3), was synthesised from 1 and imidazole in acetonitrile. In this process, $\mathbf{1}$ disintegrates and re-assembles as a mononuclear complex where the metal ion is ligated by imidazole and acetonitrile, and the 9 -aca ${ }^{-}$ligands are relegated to uncoordinated counterions. The X-ray crystal structure of $\mathbf{3}$ is shown in Fig. 2 and selected bond lengths and angles are given in Table 2. The $\mathrm{Ag}(\mathrm{I})$ ion forms short bonds to the imine $\mathrm{N}$ atom of two imidazole molcules (both $\mathrm{Ag}-\mathrm{N}=2.126(2) \AA$ ). These $\mathrm{Ag}-\mathrm{N}$ bonds are slightly longer than those found in the mononuclear imidazole complexes, $\left[\mathrm{Ag}(\mathrm{imidH})_{2}\right] \mathrm{NO}_{3}(2.115(2)$ and 2.120(2) $\AA$ ) and $\left[\mathrm{Ag}(\mathrm{imidH})_{2}\right] \mathrm{ClO}_{4}(2.131(2) \AA),{ }^{51}$ and also in the trisilver(I) complex, $\left[\mathrm{Ag}_{3}(\mathrm{imidH})_{6}\right]\left(\mathrm{ClO}_{4}\right)_{3}(2.075 \AA) .{ }^{52} \mathrm{~A}$ third ligand is coordinated to the metal in $\mathbf{3}$ and this has been modelled as a 70 : 30 disorder between acetonitrile and imidazole, respectively. The metal-nitrogen bonds to this third ligand are somewhat longer again $(\mathrm{Ag} 1-\mathrm{N} 51$ acetonitrile $=2.713(8) \AA$; Ag1-N41 imidazole $=2.588(17) \AA$ ). There is also a longer interaction with the carboxylate oxygen atom of a neighbouring 9-aca ${ }^{-}$unit $(\mathrm{Ag} 1-\mathrm{O} 2 \mathrm{~B}=3.009(2) \AA)$ (Fig. 3). In $\left[\mathrm{Ag}(\mathrm{imidH})_{2.3}\left(\mathrm{CH}_{3} \mathrm{CN}\right)_{0.7}\right]-$

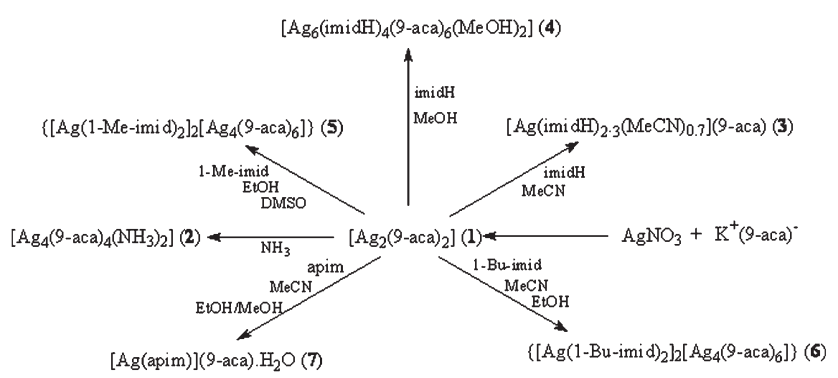

Scheme 1 Synthetic routes to the complexes. 
Table 2 Selected bond lengths $(\AA)$ and angles $\left({ }^{\circ}\right)$

\begin{tabular}{llll}
\hline Complex 3 & & N21-Ag1-N31 & $168.51(10)$ \\
Ag1-N21 & $2.126(2)$ & N21-Ag1-N41 & $96.1(6)$ \\
Ag1-N31 & $2.126(2)$ & N31-Ag1-N41 & $94.7(6)$ \\
Ag1-N41 & $2.588(17)$ & N21-Ag1-N51 & $93.7(3)$ \\
Ag1-N51 & $2.713(8)$ & N31-Ag1-N51 & $96.0(3)$ \\
Ag1-O2* & $3.009(2)$ & N21-Ag1-O2* & $93.98(8)$ \\
& & N31-Ag1-O2* & $92.38(7)$ \\
& & N41-Ag1-O2* & $76.5(3)$ \\
& & N51-Ag1-O2* & $88.78(18)$
\end{tabular}

Symmetry transformations used to generate equivalent atoms:

$*-x+1 / 2, y-1 / 2,-z+1 / 2$

Complex 4

$\begin{array}{lll}\text { Ag1-N21 } & 2.088(2) & \text { N21-Ag1-N31 } \\ \text { Ag1-N31 } & 2.089(2) & \text { O(B-Ag2-O1A) } \\ \text { Ag1-Ag2 } & 3.0651(4) & \text { O1B-Ag2-O2A } \\ \text { Ag2-O1B } & 2.218(2) & \text { O1A-Ag2-O2A } \\ \text { Ag2-O1A } & 2.416(2) & \text { O1D-Ag3-O1C } \\ \text { Ag2-O2A } & 2.424(2) & \text { O1D-Ag3-O41 } \\ \text { Ag3-O1D } & 2.1574(19) & \text { O1C-Ag3-O41 } \\ \text { Ag3-O1C } & 2.1681(19) & \text { O1D-Ag3-O2B } \\ \text { Ag3-O41 } & 2.467(2) & \text { O1C-Ag3-O2B } \\ \text { Ag3-Ag3 } & 2.8818(5) & \text { O41-Ag3-O2B }\end{array}$

Symmetry transformations used to generate equivalent atoms:

$*-x, y,-z+1 / 2$

Complex 5
$\mathrm{Ag} 1-\mathrm{O} 12 \mathrm{C}$

Ag1-O11C

$2.246(5)$

Ag1-O11A

$2.272(5)$

Ag1-O11B

$\operatorname{Ag} 1-\operatorname{Ag} 1 *$

$2.316(6)$

2.384(5)

$2.7860(12)$

$\mathrm{Ag} 1-\mathrm{Ag} 2 *$

Ag1-Ag2

2.9623(9)

$3.0079(9)$

Ag2-O12B*

Ag2-O12A

$2.188(5)$

2.193(5)

$\operatorname{Ag} 2-\operatorname{Ag} 1^{*}$

Ag3-O11E

2.9623(9)

2.222(6)

Ag3-O12E $\dagger$

2.248(6)

$2.319(6)$

Ag3-O11D

Ag3-Ag3

2.389(5)

2.7889(12)

Ag3-Ag4†

Ag3-Ag4

$2.9489(9)$

$2.9838(9)$

Ag4-O12D

2.183(5)

$2.185(5)$

2.9488(9)

2.124(9)

2.136(8)

2.131(8)

2.134(8)

O12C*1-Ag1-O11C 156.3(2)

O12C*-Ag1-O11A $\quad 100.7(2)$

O11C-Ag1-O11A 103.0(2)

O12C*-Ag1-O11B 93.4(2)

O11C-Ag1-O11B 87.79(19)

O11A-Ag1-O11B 88.2(2)

O12B*-Ag2-O12A $140.4(2)$

$\mathrm{O} 11 \mathrm{E}-\mathrm{Ag} 3-\mathrm{O} 12 \mathrm{E} \dagger \quad 158.7(2)$

O11E-Ag3-O11F 99.5(2)

$\mathrm{O} 12 \mathrm{E} \dagger-\mathrm{Ag} 3-\mathrm{O} 11 \mathrm{~F} \quad 101.7(2)$

O11E-Ag3-O11D $\quad 94.7(2$

$\mathrm{O} 12 \mathrm{E} \uparrow-\mathrm{Ag} 3-\mathrm{O} 11 \mathrm{D} \quad$ 88.4(2)

O11F-Ag3-O11D 86.8(2)

$\mathrm{O} 12 \mathrm{D} \uparrow-\mathrm{Ag} 4-\mathrm{O} 12 \mathrm{~F} \quad 140.9(2)$

N1B-Ag5-N1A $\quad 170.8(3)$

N1B-Ag5-O11B 90.4(2)

N1A-Ag5-O11B 96.1(2)

N1B-Ag5-O11A 100.9(3)

N1A-Ag5-O11A 87.1(3)

O11B-Ag5-O11A 75.53(17)

N1C-Ag6-N1D 171.2(3)

N1C-Ag6-O11D 91.8(2)

N1D-Ag6-O11D 95.4(2)

N1C-Ag6-O11F 84.1(3)

N1D-Ag6-O11F $\quad 102.8(3)$

O11D-Ag6-O11F 73.58(17)

Symmetry transformations used to generate equivalent atoms:

$*-x+1,-y,-z \dagger-x+2,-y,-z+1$

Complex 6

Ag1-O1A

Ag1-O2D

2.207(4)

2.217(4)

$2.8750(6)$

$2.9028(6)$

Ag1-Ag2

Ag2-O1E

Ag2-O1F

$\mathrm{Ag} 2-\mathrm{O} 2 \mathrm{~A}$

Ag2-O1B

$\mathrm{Ag} 2-\mathrm{Ag} 4$

Ag2-Ag3

Ag3-O1C

$\mathrm{Ag} 3-\mathrm{O} 2 \mathrm{~B}$

Ag3-Ag4

Ag4-O1D

$\mathrm{Ag} 4-\mathrm{O} 2 \mathrm{C}$

$\mathrm{Ag} 4-\mathrm{O} 2 \mathrm{~F}$

$\mathrm{Ag} 4-\mathrm{O} 2 \mathrm{E}$

2.222(4)

$2.226(4)$

2.335(4)

2.357(4)

$2.8365(5)$

$2.8770(6)$

2.174(4)

2.192(4)

2.8949(6)

$2.275(4)$

2.304(4)

2.354(4)

2.355(4)

$2.116(5)$
O1A-Ag1-O2D

$\mathrm{O} 1 \mathrm{E}-\mathrm{Ag} 2-\mathrm{O} 1 \mathrm{~F}$

$\mathrm{O} 1 \mathrm{E}-\mathrm{Ag} 2-\mathrm{O} 2 \mathrm{~A}$

$\mathrm{O} 1 \mathrm{~F}-\mathrm{Ag} 2-\mathrm{O} 2 \mathrm{~A}$

$\mathrm{O} 1 \mathrm{E}-\mathrm{Ag} 2-\mathrm{O} 1 \mathrm{~B}$

O1F-Ag2-O1B

O2A-Ag2-O1B

O1C-Ag3-O2B

O1D-Ag4-O2C

O1D-Ag4-O2F

$\mathrm{O} 2 \mathrm{C}-\mathrm{Ag} 4-\mathrm{O} 2 \mathrm{~F}$

O1D-Ag4-O2E

$\mathrm{O} 2 \mathrm{C}-\mathrm{Ag} 4-\mathrm{O} 2 \mathrm{E}$

$\mathrm{O} 2 \mathrm{~F}-\mathrm{Ag} 4-\mathrm{O} 2 \mathrm{E}$

N1A-Ag5-N1B

N1A-Ag5-O2A

N1B-Ag5-O2A

N1A-Ag5-O1B
91.25(14)

94.95(15)

99.15(16)

93.86(14)

89.46(15)

93.00(15)

92.01(17)

93.44(16)

$89.43(15)$

$89.53(16)$
Table 2 (Contd.)

\begin{tabular}{llll}
\hline Ag5-N1B & $2.117(5)$ & N1B-Ag5-O1B & $92.03(16)$ \\
Ag6-N1D & $2.131(5)$ & O2A-Ag5-O1B & $76.98(11)$ \\
Ag6-N1C & $2.131(5)$ & N1D-Ag6-N1C & $175.1(2)$ \\
& & N1D-Ag6-O1D & $90.55(19)$ \\
& & N1C-Ag6-O1D & $94.19(19)$ \\
& & N1D-Ag6-O2C & $97.24(17)$ \\
& & N1C-Ag6-O2C & $85.17(16)$ \\
Ag7-O1G & $2.196(4)$ & O1D-Ag6-O2C & $73.86(12)$ \\
Ag7-O2J & $2.202(4)$ & O1G-Ag7-O2J & $132.37(16)$ \\
Ag7-O1L & $2.564(4)$ & O1K-Ag8-O2L & $105.68(16)$ \\
Ag7-Ag10 & $2.8760(6)$ & O1K-Ag8-O2G & $153.12(15)$ \\
Ag7-Ag8 & $2.9646(6)$ & O2L-Ag8-O2G & $104.46(16)$ \\
Ag8-O1K & $2.217(4)$ & O1K-Ag8-O1H & $104.54(16)$ \\
Ag8-O2L & $2.257(4)$ & O2L-Ag8-O1H & $85.64(14)$ \\
Ag8-O2G & $2.301(4)$ & O2G-Ag8-O1H & $93.64(14)$ \\
Ag8-O1H & $2.382(4)$ & O1I-Ag9-O2H & $135.17(16)$ \\
Ag8-Ag10 & $2.8165(5)$ & O2I-Ag10-O1J & $88.66(15)$ \\
Ag8-Ag9 & $2.8544(6)$ & O2I-Ag10-O2K & $95.31(16)$ \\
Ag9-O1I & $2.178(4)$ & O1J-Ag10-O2K & $109.95(17)$ \\
Ag9-O2H & $2.203(4)$ & O2I-Ag10-O1L & $99.16(15)$ \\
Ag9-Ag10 & $2.9511(6)$ & O1J-Ag10-O1L & $87.68(16)$ \\
Ag10-O2I & $2.286(4)$ & O2K-Ag10-O1L & $157.45(14)$ \\
Ag10-O1J & $2.304(4)$ & N1E-Ag11-N1F & $176.84(19)$ \\
Ag10-O2K & $2.309(4)$ & N1E-Ag11-O1H & $93.65(16)$ \\
Ag10-O1L & $2.374(4)$ & N1F-Ag11-O1H & $89.24(16)$ \\
Ag11-N1E & $2.112(5)$ & N1E-Ag11-O2G & $87.63(17)$ \\
Ag11-N1F & $2.113(5)$ & N1F-Ag11-O2G & $94.29(16)$ \\
Ag12-N1H & $2.122(5)$ & O1H-Ag11-O2G & $76.30(11)$ \\
Ag12-N1G & $2.124(5)$ & N1H-Ag12-N1G & $175.0(2)$ \\
Complex & & N1H-Ag12-O1J & $94.68(18)$ \\
& & N1G-Ag12-O1J & $90.14(18)$ \\
& & N1H-Ag12-O2I & $86.61(17)$ \\
N1G-Ag12-O2I & $95.99(18)$ \\
Ag & O1J-Ag12-O2I & $73.43(12)$
\end{tabular}

Complex 7

Ag1-N1

2.0841(18)

Ag1-N3* 2.1069(18) N1-Ag1-N3*

Symmetry transformations used to generate equivalent atoms:

* $-x+1 / 2, y+1 / 2, z$

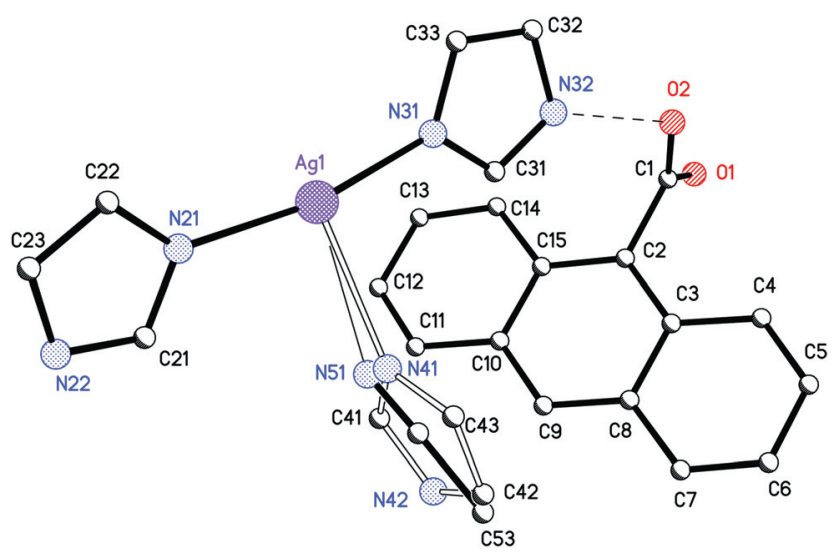

$154.83(15)$

$108.55(15)$

$135.29(16)$

$107.09(18)$

$102.37(15)$

$155.64(13)$

$176.98(18)$
Fig. 2 The asymmetric unit of $\left[\mathrm{Ag}(\mathrm{imidH})_{2.3}\left(\mathrm{CH}_{3} \mathrm{CN}\right)_{0.7}\right](9$-aca) (3) showing the disorder of one imidH with $\mathrm{CH}_{3} \mathrm{CN}$.

(9-aca) (3), the metal is coordinated approximately linearly with whilst the third ligand lies almost perpendicular (N21-Ag1-N51 $\left.=93.7(3)^{\circ}\right)$. The structure is linked into chains by hydrogen bonding between carboxylate oxygens and the hydrogen atoms on the pyrrole-type nitrogens $(\mathrm{N}-\mathrm{H})$ of the imidazoles (Fig. 3). the first two imidazole ligands $\left(\mathrm{N} 21-\mathrm{Ag} 1-\mathrm{N} 31=168.51(10)^{\circ}\right)$, 
Table 3 Antimicrobial activities of complexes 1-7, silver nitrate and the clinically used compounds, ketoconazole and silver sulfadiazine. MIC values are given in $\mu \mathrm{M}$ concentrations of complex and $\mathrm{Ag}(\mathrm{I})$ ions (in brackets)

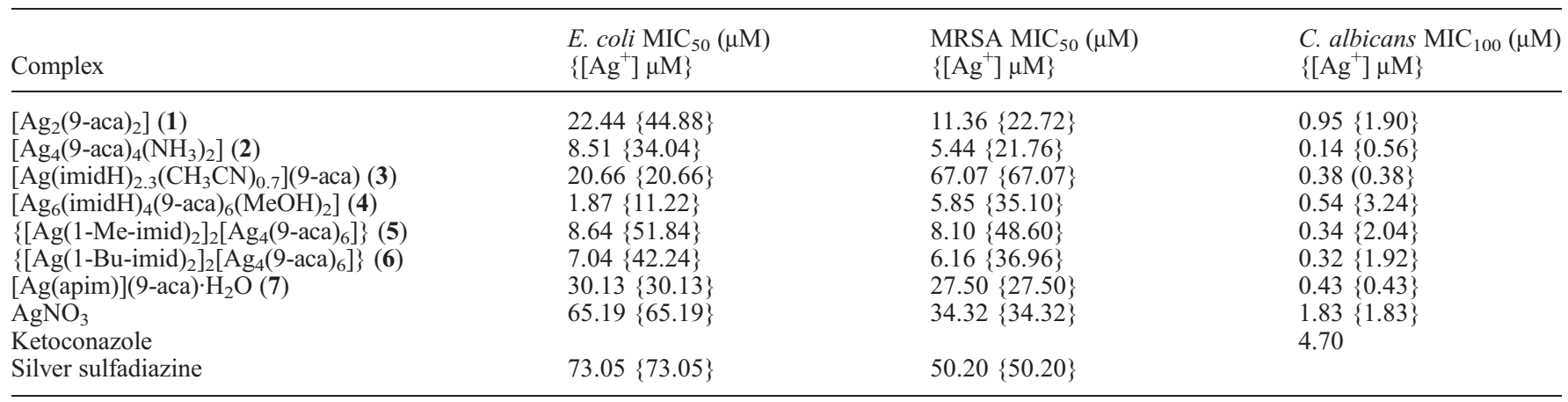

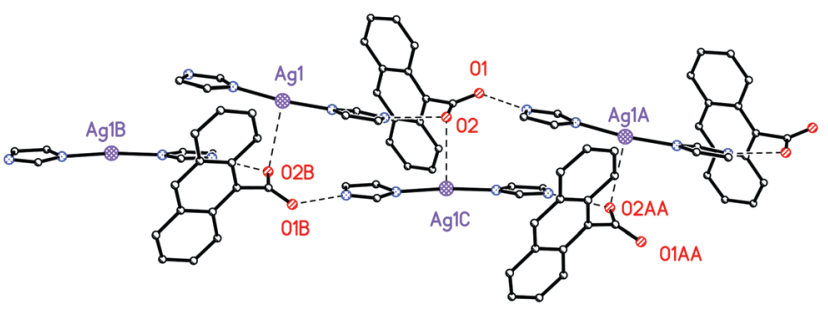

Fig. 3 Weak interactions of the silver(I) centre with the carboxylate oxygen atoms and the H-bonding between the imidazole $\mathrm{N}-\mathrm{H}$ and carboxylate oxygens in $\left[\mathrm{Ag}(\mathrm{imidH})_{2.3}\left(\mathrm{CH}_{3} \mathrm{CN}\right)_{0.7}\right](9$-aca) (3). The disordered solvate ligand has been omitted for clarity and H-bonds are represented by dashed lines.

This assembly is further supported by $\pi-\pi$ stacking of the imidazole groups, with a centroid-centroid distance of $3.64 \AA$.

The IR spectrum of 3 exhibits a weak band at $2250 \mathrm{~cm}^{-1}$ for the $\mathrm{C} \equiv \mathrm{N}$ bond stretching vibration. Bands are also observed at 3436 and $1072 \mathrm{~cm}^{-1}$, corresponding to the $\mathrm{N}-\mathrm{H}$ and $\mathrm{C}-\mathrm{N}$ stretching vibrations of imidazole, respectively. ${ }^{51}$ Bands for the anthracene ring system occur at 1625,760 and $739 \mathrm{~cm}^{-1}$. 53,54 Carboxylate $v_{(\mathrm{OCO}) \text { asym }}$ and $v_{(\mathrm{OCO}) \text { sym }}$ vibrations are present at 1562 and $1426 \mathrm{~cm}^{-1}$, respectively, giving a $\Delta_{(\mathrm{OCO})}$ value of $136 \mathrm{~cm}^{-1}$. This value indicates a bridging carboxylate which, in this case, is associated with the pseudo-bridging via hydrogen bonds. ${ }^{55}$

$\left[\mathrm{Ag}_{6}(\mathrm{imidH})_{4}(9-\mathrm{aca})_{6}(\mathrm{MeOH})_{2}\right]$ (4) was synthesised from 1 and imidazole in methanol, with a yield of $44 \%$. Thus, a minor change in the reaction conditions (methanol as solvent as opposed to acetonitrile) causes a dramatic change in the product formulation. The X-ray crystal structure of the hexanuclear complex 4 (Fig. 4 and Table 2) shows that there is a two-fold axis through the molecule and that it contains both three- and five-coordinate silver(I) ions (Fig. 5). The $\mathrm{Ag} 1-\mathrm{Ag} 2$ bond length is 3.0651(4) $\AA$, while the $\mathrm{Ag} 3-\mathrm{Ag} 3 \mathrm{~A}$ bond is significantly shorter at 2.8818(5) $\AA$. Both of these $\mathrm{Ag}-\mathrm{Ag}$ distances are close to that in metallic silver $(2.889(6) \AA)$ and are much shorter than the sum of the van der Waals radii of two $\operatorname{Ag}(0)$ atoms (3.44 $\AA$ ), implying the existence of $d^{10}-d^{10}$ interactions between two closed-shell $\operatorname{Ag}(\mathrm{I})$ ions. Such argentophilic interactions have been observed in a large number of multinuclear $\mathrm{Ag}(\mathrm{I}) \mathrm{com}-$ plexes. ${ }^{56} \mathrm{In} \mathbf{4}, \mathrm{Ag} 1$ is coordinated approximately linearly by two imidazoles (N21-Ag1-N31 bond angle of $\left.174.33(10)^{\circ}\right)$ with identical $\mathrm{Ag}-\mathrm{N}$ bond lengths (2.088(2) $\AA$ ). These latter bonds

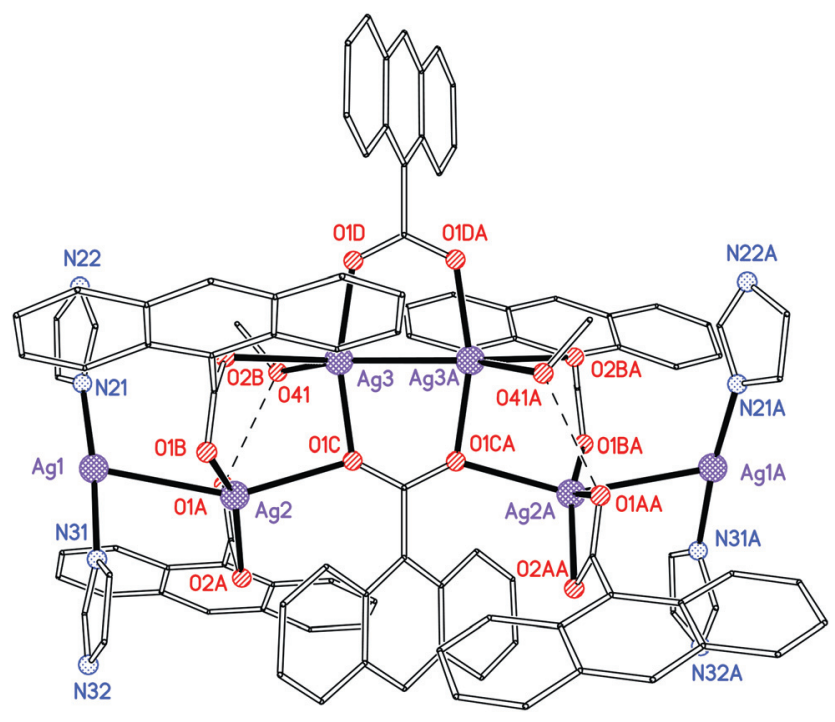

Fig. 4 Structure of $\left[\mathrm{Ag}_{6}(\mathrm{imidH})_{4}(9 \text {-aca })_{6}(\mathrm{MeOH})_{2}\right]$ (4). The two-fold axis lies in the plane of the page and bisects the Ag3-Ag3 A vector (symmetry code $-x, y,-z+1 / 2$ ). H-bonds are represented by dashed lines.

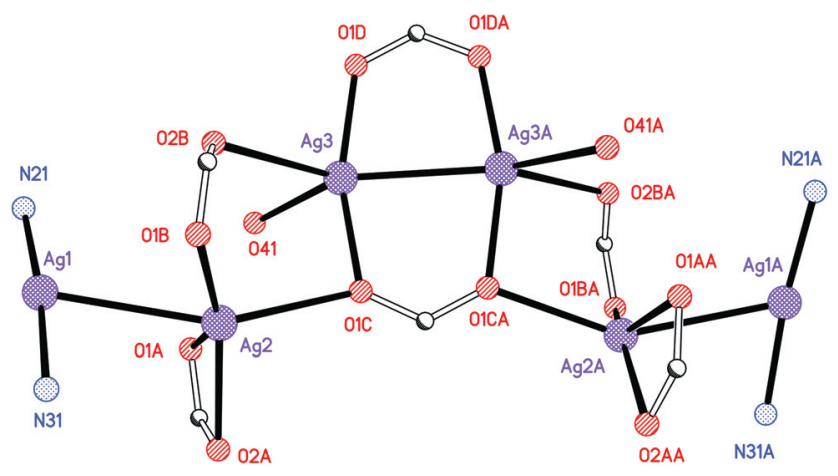

Fig. 5 Coordination sphere of $\left[\mathrm{Ag}_{6}(\mathrm{imidH})_{4}(9-\mathrm{aca})_{6}(\mathrm{MeOH})_{2}\right](4)$ with the imidazole and anthracene rings omitted for clarity.

are slightly shorter than the corresponding $\mathrm{Ag}-\mathrm{N}$ bond (2.126(2) $\AA)$ of the ordered imidazole in $\left[\mathrm{Ag}(\mathrm{imidH})_{2.3}\left(\mathrm{CH}_{3} \mathrm{CN}\right)_{0.7}\right](9$-aca $)$ (3). In complex (4), $\mathrm{Ag} 2$ is coordinated to three different carboxylate groups as well as being bonded to $\mathrm{Ag} 1 . \mathrm{Ag} 3$ is also coordinated to three different carboxylate groups, plus the oxygen of a coordinated methanol molecule and another silver ion (Ag3A). 
Two of the carboxylate ligands are in the syn-syn configuration (O1C and O1Ca, O1D and O1DA), two are syn-anti (O1B and $\mathrm{O} 2 \mathrm{~B}, \mathrm{O} 1 \mathrm{BA}$ and $\mathrm{O} 2 \mathrm{BA}$ ) and two are coordinated in a symmetrical, bidentate chelation mode (O1A and O2A, O1AA and $\mathrm{O} 2 \mathrm{AA}$ ). There is also intramolecular $\mathrm{H}$-bonding between the $\mathrm{OH}$ of the alcohol group and a neighbouring carboxylate oxygen atom (O41-O1A 2.782(3) $\AA$ ), as well as intermolecular Hbonding between the amine hydrogen of the imidazole and a carboxylate oxygen of a neighbouring 9-aca ${ }^{-}$ligand (N22-O2A 2.796(3) $\AA$ under symmetry operation $-x+1 / 2, y-1 / 2, z$ and N32-O2B, 2.815(3) under $-x+1 / 2, y+1 / 2, z)$. A very weak $\pi$-interaction between $\operatorname{Ag}(1)$ and the anthracene ring of a neighbouring molecule is also observed. The structure of $\mathbf{4}$ is quite different to that of the recently reported, hexanuclear, centrosymmetric complex, $\left[\mathrm{Ag}_{6}(\mathrm{dmp})_{2}(9 \text {-aca })_{6}\right](\mathrm{dmp}=2,6$-dimethylpyridine), ${ }^{57}$ prepared by reacting $\mathrm{AgNO}_{3}$ with 9-acaH in the presence of dmp. In this complex, all six $\mathrm{Ag}(\mathrm{I})$ ions are ligated by carboxylate oxygen atoms, and the two heterocyclic, N-donor dmp ligands are bonded to separate metal centres. In addition, the solid state structure of $\left[\operatorname{Ag}_{6}(\mathrm{dmp})_{2}(9 \text {-aca })_{6}\right]$ exhibits intramolecular and intermolecular anthracene $\mathrm{C}-\mathrm{H} \cdots \mathrm{Ag}$ interactions as well as $\pi-\pi$ stacking interactions. The metal coordination geometry within the hexanuclear core of $\mathbf{4}$ is also very different to that recently reported for a number of hexa-Ag(I) thiosemicarbazone complexes and, furthermore, the shortest $\mathrm{Ag}-\mathrm{Ag}$ distances in the latter complexes are significantly longer than in $4 .^{57-59}$

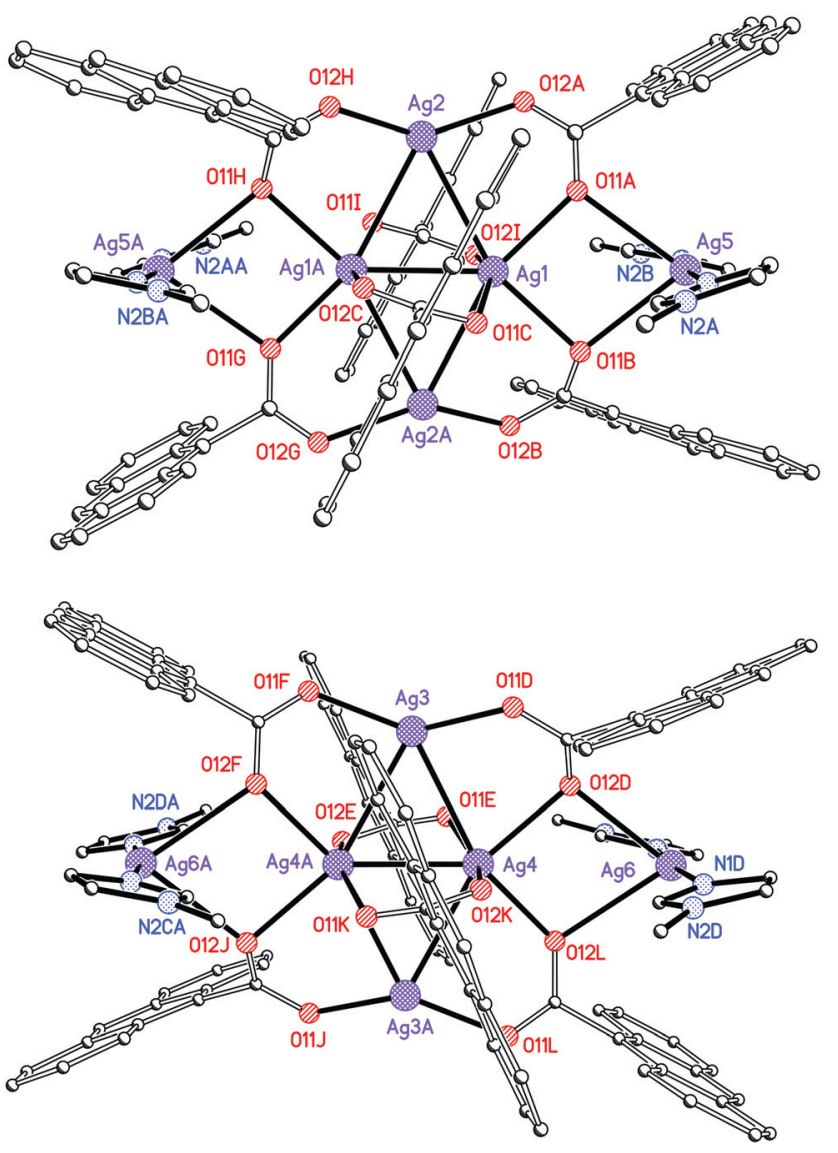

Fig. 6 The two independent molecules of $\left[\mathrm{Ag}(1-\mathrm{Me}-\mathrm{imid})_{2}\right]_{2}\left[\mathrm{Ag}_{4}(9-\right.$ aca $)_{6}$ (5) illustrating the difference in arrangement of the anthracene ligands.
The IR spectrum of $\mathbf{4}$ has peaks at 3448 and $1091 \mathrm{~cm}^{-1}$ for the $\mathrm{O}-\mathrm{H}$ and $\mathrm{C}-\mathrm{N}$ stretching vibrations of $\mathrm{MeOH}$ and imidazole, respectively. Distinctive bands for the vibrations of the anthracene ring system appear at 1625,760 and $736 \mathrm{~cm}^{-1}$. Carboxylate $v_{(\mathrm{OCO}) \text { asym }}$ and $v_{(\mathrm{OCO}) \text { sym }}$ vibrations occur at 1538 and $1433 \mathrm{~cm}^{-1}$, respectively, giving a $\Delta_{(\mathrm{OCO})}$ value of $105 \mathrm{~cm}^{-1}$ and implying the presence of bridging carboxylates.

The initial beige precipitate which formed upon reacting $\mathbf{1}$ with 1-methylimidazole (1-Me-imidH) in ethanol was recrystallised from DMSO to give $\left\{\left[\mathrm{Ag}(1-\mathrm{Me}-\mathrm{imid})_{2}\right]_{2}\left[\mathrm{Ag}_{4}(9-\mathrm{aca})_{6}\right]\right\}$ (5). The X-ray crystal structure of 5 (Fig. 6 and Table 2) shows it to consist of two independent, centrosymmetric molecules which differ chiefly in the angle between the planes of the anthracene ligands. Each molecule of $\mathbf{5}$ contains a dianionic, complex central core, $\left[\operatorname{Ag}_{4}(9-a c a)_{6}\right]^{2-}$, with the two complex cations, $\left[\mathrm{Ag}(1-\mathrm{Me}-\mathrm{imidH})_{2}\right]^{+}$, on the periphery of the molecule. It is the manner in which these two dications are each linked to the tetranuclear core by a bridging carboxylate oxygen atom that principally distinguishes this structure from 4 .

The central tetrasilver(I) cluster in $\mathbf{5}$ contains $\mathrm{Ag}-\mathrm{Ag}$ bond lengths ranging from 2.786 to $3.009 \AA$, and the average distance from a core metal to a peripheral metal is $5.821 \AA$ (Fig. 7). The $\mathrm{Ag} 1-\mathrm{Ag} 1 \mathrm{~A}$ distance of $2.786 \AA$ in $\mathbf{5}$ is the shortest in the present family of $\operatorname{Ag}(\mathrm{I})$ anthracenecarboxylate complexes and it is also significantly smaller than any argentophilic interactions found in $\left[\mathrm{Ag}_{6}(\mathrm{dmp})_{2}(9 \text {-aca })_{6}\right]$ (minimum $\mathrm{Ag}-\mathrm{Ag}$ is $\left.2.895 \AA\right) .{ }^{57} \mathrm{In}$ complex 5, two 9-aca ${ }^{-}$ligands (O11C, O12C and O11I, O12I) are coordinated in a syn-syn fashion to the central silver(I) ions (Ag1, Ag1A), and the other four carboxylate ligands are
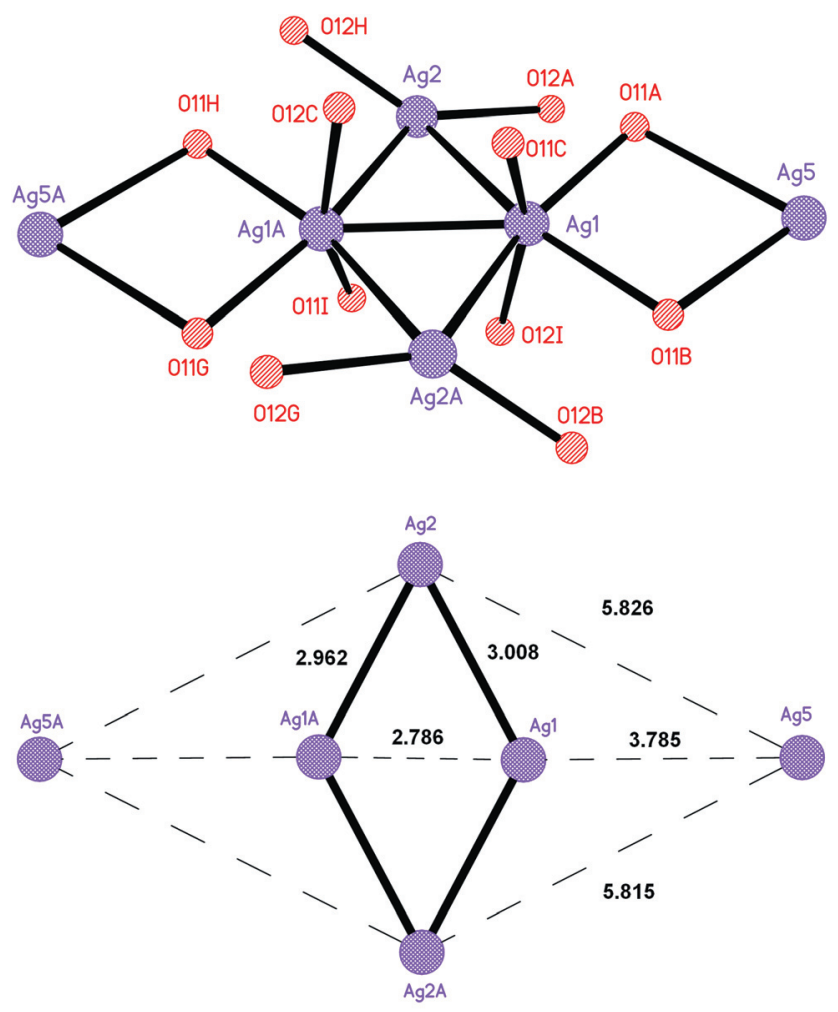

Fig. 7 Simplified structures of $\left[\mathrm{Ag}(1-\mathrm{Me}-\mathrm{imid})_{2}\right]_{2}\left[\mathrm{Ag}_{4}(9-\mathrm{aca})_{6}\right]$ (5) showing (a) $\mathrm{Ag}-\mathrm{Ag}$ and $\mathrm{Ag}-\mathrm{O}$ bonding and (b) $\mathrm{Ag}-\mathrm{Ag}$ bond distances ( $\AA$ ) for one of the molecules. 

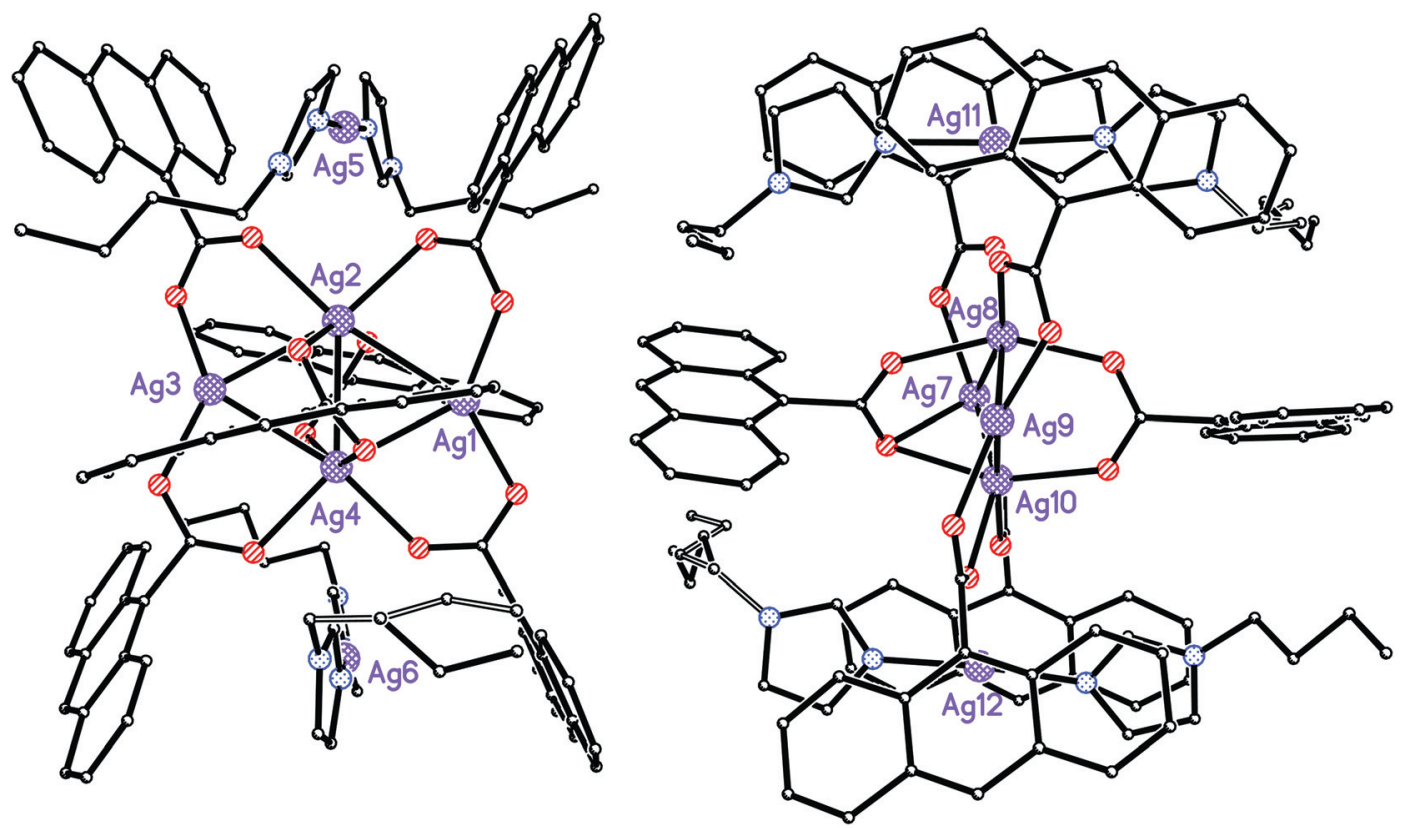

Fig. 8 X-ray crystal structure of $\left[\mathrm{Ag}(1-\mathrm{Bu} \text {-imid })_{2}\right]_{2}\left[\mathrm{Ag}_{4}(9 \text {-aca })_{6}\right](6)$ showing the two independent assemblies.
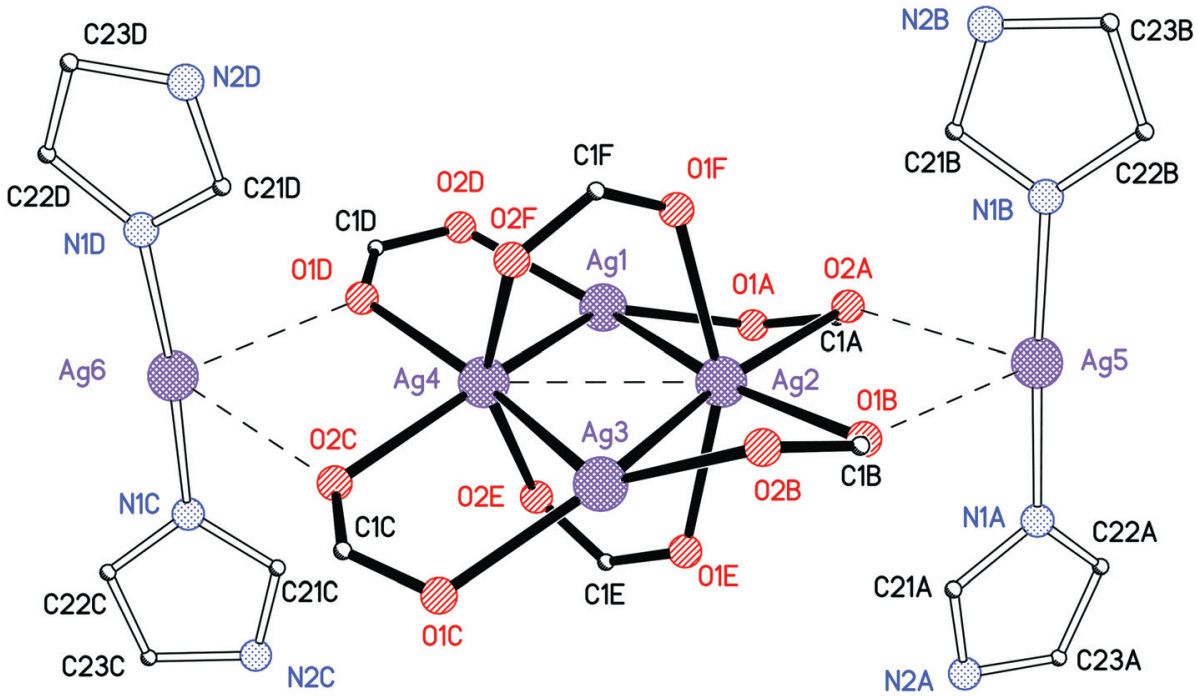

Fig. 9 Structure of one molecule of $\left\{\left[\mathrm{Ag}(1-\mathrm{Bu}-\mathrm{imid})_{2}\right]_{2}\left[\mathrm{Ag}_{4}(9-\mathrm{aca})_{6}\right]\right\}$ (6) with the anthracene rings and alkyl chains removed for clarity.

coordinated to two central silver(I) ions and one peripheral silver (I) ion. The average core Ag-O bond length is $2.304 \AA$ (e.g. $\mathrm{Ag} 1-\mathrm{O} 11)$ and the average peripheral $\mathrm{Ag}-\mathrm{O}$ bond length is $2.671 \AA$ (e.g. (Ag5-O11A). The 1-Me-imid ligands are coordinated to the metals through the imine $\mathrm{N}$ atom and lie in an approximately linear arrangement (N1A-Ag5-N1B bond angle is $171.10^{\circ}$ ). The methyl groups on each of the two imidazole ligands are cis to each other and are orientated towards the centre of the molecule.

The IR spectrum of 5 contains bands at 1621, 772 and $736 \mathrm{~cm}^{-1}$ for the anthracene ring system, and a band for the $\mathrm{C}-\mathrm{N}$ stretching vibration of the imidazole ring at $1087 \mathrm{~cm}^{-1}$. The carboxylate $v_{(\mathrm{OCO}) \text { asym }}$ and $v_{(\mathrm{OCO}) \text { sym }}$ stretching vibrations occur at 1565 and $1428 \mathrm{~cm}^{-1}$, respectively, giving a $\Delta_{(\mathrm{OCO})}$ value of $137 \mathrm{~cm}^{-1}$. This value indicates the presence of carboxylates with a chelating and/or bridging mode of coordination.

The reaction of $\mathbf{1}$ with 1-butylimidazole in acetonitrile produced a beige solid which, upon recrystallisation from ethanol, yielded $\left\{\left[\mathrm{Ag}(1-\mathrm{Bu} \text {-imid })_{2}\right]_{2}\left[\mathrm{Ag}_{4}(9 \text {-aca })_{6}\right]\right\}$ (6). The X-ray crystal structure of 6 (Fig. 8, Table 2) shows two very similar but independent assemblies within the asymmetric unit and orientated at approximately $90^{\circ}$ to each other. There is also some disorder within the butyl chains of the imidazole ligands. The complex contains two-, four- and six-coordinate silver(I) ions (Fig. 9). Two of the metals are coordinated approximately linearly to the imine nitrogen atoms of two 1-Bu-imid ligands (bond angles of 176.98(18), 175.1(2), 176.84(19) and 175.0(2) $\left.{ }^{\circ}\right)$, with an average $\mathrm{Ag}-\mathrm{N}$ bond length of $2.124 \AA$. There are also longer 


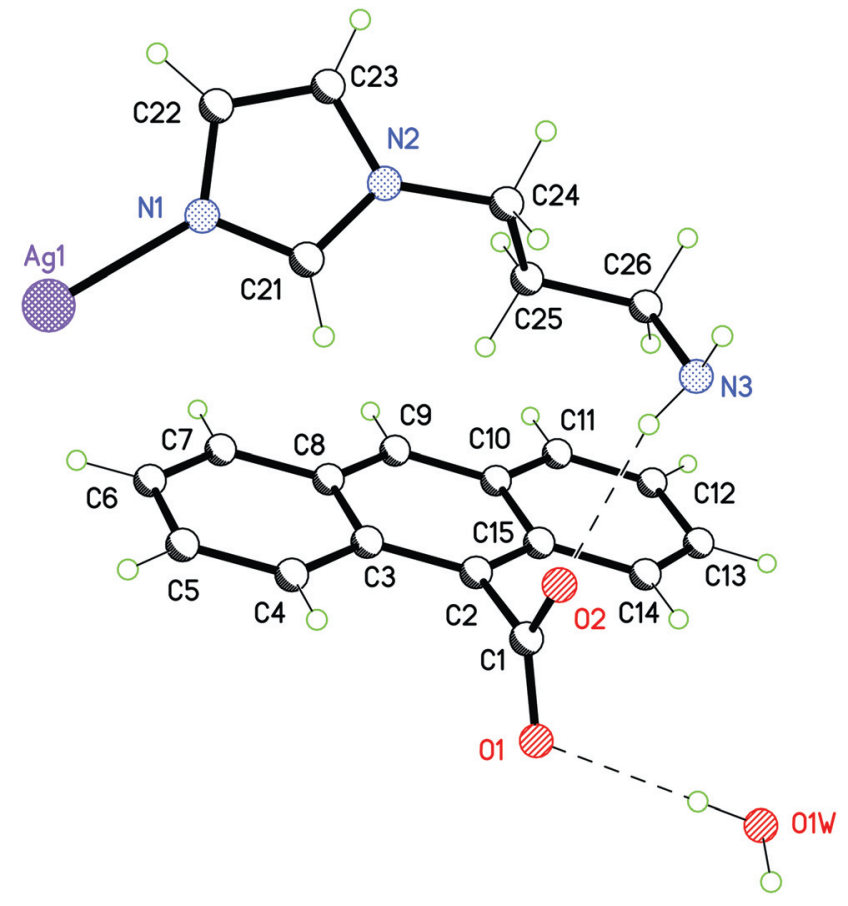

Fig. 10 Structure of one asymmetric unit of $[\mathrm{Ag}(\operatorname{apim})](9-\mathrm{aca}) \cdot \mathrm{H}_{2} \mathrm{O}$ (7).

interactions of these silver ions with carboxylate oxygen atoms at the central core of the molecule (Ag5-O2A, Ag5-O1B, Ag6-O2C and Ag6-O1D bond lengths of 2.696(4), 2.809(4), 2.756(4) and 2.603(4) $\AA$, respectively). Within the central, dicationic $\left[\mathrm{Ag}_{4}(9-\mathrm{aca})_{6}\right]^{2-}$ core there are five $\mathrm{Ag}-\mathrm{Ag}$ bonds, with lengths ranging from $2.8165(5)$ to $2.9646(6) \AA$. All of the anthracene ligands use both of their carboxylate oxygen atoms to coordinate to two different silver ions in a syn-syn binding mode. There are no intramolecular or intermolecular $\pi-\pi$ interactions between either the anthracene or the imidazole rings. The structure of $\mathbf{6}$ is very similar to that of $\mathbf{5}$, indicating that the change in the length of the alkyl chain (from methyl to butyl) on the tertiary $\mathrm{N}$ atom of the imidazole ring does not appear to affect the core structure of the product.

The IR spectrum of $\mathbf{6}$ contains bands for the anthracene rings at 1622,759 and $732 \mathrm{~cm}^{-1}$. The band representing the $\mathrm{C}-\mathrm{N}$ stretching vibration of the 1-Bu-imid ligands occur at $1085 \mathrm{~cm}^{-1}$. Carboxylate $v_{(\mathrm{OCO}) \text { asym }}$ and $v_{(\mathrm{OCO}) \text { sym }}$ vibrations appear at 1565 and $1427 \mathrm{~cm}^{-1}$, respectively, giving a $\Delta_{(\mathrm{OCO})}$ value of $138 \mathrm{~cm}^{-1}$ and indicating that the carboxylate ligands are coordinated in either a chelating or a bridging mode.

$[\mathrm{Ag}($ apim $)](9-\mathrm{aca}) \cdot \mathrm{H}_{2} \mathrm{O}(7)$ was synthesised in high yield from 1 and 1-(3-aminopropyl)-imidazole (apim) in acetonitrile. The X-ray crystal structure of 7 (Fig. 10, Table 2) shows the metal bonded to the imine nitrogen atom of the imidazole ring (Ag1$\mathrm{N} 1=2.0841(18) \AA$ ). The metals and the apim ligands bond together to form 1-D, zig-zag polymeric chains (Fig. 11) with the silver being coordinated approximately linearly to the imine nitrogen of one apim and the nitrogen of the pendant amine function of another imidazole $(\mathrm{Ag} 1-\mathrm{N} 3 \mathrm{~A}=2.1069(18) \AA$ and $\left.\mathrm{N} 1-\mathrm{Ag} 1-\mathrm{N} 3 \mathrm{~A}=177.76(7)^{\circ}\right) . \pi-\pi$ Stacking interactions are also observed between the imidazole rings, creating 2-D sheets (ESI $\dagger$ Fig. a). The water molecule of hydration links to the anionic 9-aca ${ }^{-}$units through $\mathrm{H}$-bonds forming polymeric chains which zig-zag in-and-out through the spaces in the $[\operatorname{Ag}(\operatorname{apim})]_{n}{ }^{n+}$ sheets (ESI $\dagger$ Fig. b). There are also H-bonding interactions linking a carboxylate oxygen to the hydrogen of the pendant amine group (ESI $\uparrow$ Fig. c). Due to the relatively long distance between the sheets, there are no $\pi-\pi$ interactions involving the anthracene rings. The structurally similar and previously characterised $^{60}$ apim complex, $[\mathrm{Ag}($ apim $)] \mathrm{ClO}_{4}$, also shows the same type of zig-zag arrangement of polymeric $[\mathrm{Ag}(\operatorname{apim})]_{n}{ }^{n+}$ chains, but this complex has weak metal-anion $\left(\mathrm{ClO}_{4}{ }^{-}\right)$interactions which are not present in 7 .

The IR spectrum of 7 contains bands at 3427 and $3236 \mathrm{~cm}^{-1}$ corresponding to the apim $\mathrm{NH}_{2}$ stretching vibrations, and a band at $1089 \mathrm{~cm}^{-1}$ for the $\mathrm{C}-\mathrm{N}$ stretching vibration of the imidazole ring. Two bands are present at 761 and $735 \mathrm{~cm}^{-1}$ for the stretching vibrations of the anthracene ring system, but the third band, which is usually located at approximately $1625 \mathrm{~cm}^{-1}$, is masked by the strong $v_{(\mathrm{OCO}) \text { asym }}$ carboxylate stretching band centred at $1568 \mathrm{~cm}^{-1}$. The $v_{(\mathrm{OCO}) \mathrm{sym}}$ stretching vibration occurs at $1426 \mathrm{~cm}^{-1}$, thus giving a $\Delta_{(\mathrm{OCO})}$ value of $142 \mathrm{~cm}^{-1}$. Although this value implies that the carboxylate is either chelating or brid$\operatorname{ging}^{55}$ it is evident from the X-ray crystal structure of the complex that this is not the case. Thus, it must be stressed that coordination mode assignments based on $\Delta_{(\mathrm{OCO})}$ values ${ }^{55}$ can, indeed, be quite tentative.

In summary, it is evident from the formulations of complexes 3-7 that a slight change in either the reaction solvent or the structure of the imidazole ligand employed during the synthesis can have a marked effect on the structure of the isolated product. Unsubstituted imidazole leads to the mononuclear species, 3 . Having an alkyl substituent on the tertiary $\mathrm{N}$ atom of the imidazole gives the hexanuclear complexes, 4, 5 and 6. When the alkyl substituent carries an amine functionality on its terminus the polymeric complex 7 forms.

\section{Antimicrobial activity}

The silver(I) complexes, 1-7, the simple silver(I) salt, silver nitrate, and selected, known antimicrobial drugs (antibacterial silver sulfadiazine and antifungal ketoconazole) were screened, in vitro, for their ability to inhibit the growth of pathogenic bacterial and fungal cells. Activities (as $\mathrm{MIC}_{50}$ or $\mathrm{MIC}_{100}$ values) are reported (Table 3) as $\mu \mathrm{M}$ concentrations of the complexes and also as $\mu \mathrm{M}$ concentrations of administered $\mathrm{Ag}(\mathrm{I})$ ion in consideration of the different amounts of $\operatorname{Ag}(\mathrm{I})$ ions present in the various complexes. Test solutions (or suspensions) were made by dissolving the sample in DMSO and diluting with water to yield the required concentration. The maximum DMSO concentration in any test solution was $0.5 \% \mathrm{v} / \mathrm{v}$, and at this level the DMSO does not inhibit the growth of the microbial cells. The metal-free ligands (9-acaH and the various imidazoles) were also screened for their biological activity and all were inactive at a concentration of $\leq 100 \mu \mathrm{g} \mathrm{cm}{ }^{-3}$.

In terms of both complex concentration and the concentration of $\mathrm{Ag}(\mathrm{I})$ ions, 1-7 were all more active than $\mathrm{AgNO}_{3}$ and silver sulfadiazine against Gram-negative E. coli. Against Gram-positive MRSA, only 3 was less active, in terms of complex concentration, than $\mathrm{AgNO}_{3}$. Comparisons made on the basis of $\mathrm{Ag}(\mathrm{I})$ ion concentration reveal that only complexes $\mathbf{1 , 2}$ and 7 were 


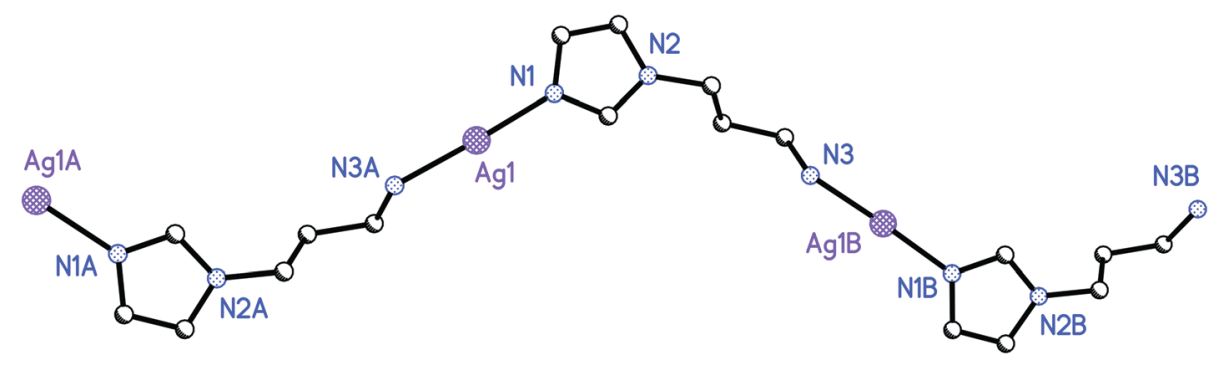

Fig. $11[\mathrm{Ag}(\mathrm{apim})]_{n}{ }^{n+}$ cationic polymer chains in the structure of $[\mathrm{Ag}(\operatorname{apim})](9-\mathrm{aca}) \cdot \mathrm{H}_{2} \mathrm{O}(7)$.

more active against MRSA than $\mathrm{AgNO}_{3}$. In terms of $\mathrm{Ag}(\mathrm{I})$ ion concentration, 1, 2 and 7 were more active than $\mathrm{AgNO}_{3}$ against both species of bacteria. The structurally similar double complex salts, 5 and $\mathbf{6}$, displayed similar antibacterial properties.

With respect to complex concentrations, 1-7 were all considerably more active against $C$. albicans than both ketoconazole and $\mathrm{AgNO}_{3}$ (Table 3). However, as a function of $\mathrm{Ag}(\mathrm{I})$ ion concentration, only 2, 3 and 7 were a lot more active than $\mathrm{AgNO}_{3}$. The latter three complexes, which all contain $\mathrm{N}$-donor imidazole ligands, were more active than the parent carboxylate complex, 1. Complexes $\mathbf{5}$ and $\mathbf{6}$, which contain imidazole ligands carrying substituents $(\mathrm{Me}$ or $\mathrm{Bu})$ on the $\mathrm{N} 1$ atom of the heterocyclic ring, and which also have ligated $9-$ aca $^{-}$anions, appear to be only marginally more active than hexanuclear 4 , which has un-substituted imidazoles coordinated to two of the metal centres. Against all three microbial species, and in terms of $\operatorname{Ag}(\mathrm{I})$ ion content, only $\mathbf{2}$ and $\mathbf{7}$ were significantly more active than $\mathrm{AgNO}_{3}$.

In vivo toxicity profiling was carried out using the G. mellonella insect model. G. mellonella larvae were administered with test solutions (or suspensions) by injection directly into the haemocoel through the last pro-leg. Survival was monitored after $72 \mathrm{~h}$ and death was assessed by the lack of movement in response to stimulus together with discoloration of the cuticle. The toxicity of all of the test samples was assessed at two different concentrations: $100 \mu \mathrm{g} \mathrm{cm}^{-3}$ and twice their $\mathrm{MIC}_{100}$ value. Silver nitrate and ketoconazole were used as reference standards. It was found that all of the larvae survived the highest administered concentration $\left(100 \mu \mathrm{g} \mathrm{cm}^{-3}\right)$ of $\mathrm{AgNO}_{3}$, ketoconazole and complexes 1-7. Two types of in vivo antifungal screening protocols were conducted using the larvae: (i) prophylactic treatment and (ii) the treatment of infection (pre-infected larvae). The larvae were infected with a lethal dose of $C$. albicans $\left(2 \times 10^{6}\right.$ fungal cells) in each of the two screening protocols. For prophylactic treatment, the test compound was administered $1 \mathrm{~h}$ prior to infection with $C$. albicans cells, while for the treatment of infection experiments the compound was administered $1 \mathrm{~h}$ after infection with $C$. albicans. In each case, larvae survival was assessed after a $72 \mathrm{~h}$ interval and the results are presented in Fig. 12.

Complex 2, administered prophylactically at a concentration of $100 \mu \mathrm{g} \mathrm{cm}^{-3}$, significantly increased the survival rate $(90 \%)$ of G. mellonella larvae $72 \mathrm{~h}$ after infection with a lethal dose of C. albicans cells. This response was superior to that given by $\mathrm{AgNO}_{3}(80 \%)$ and ketoconazole (75\%), which were, in turn, better than that the other $\operatorname{Ag}(\mathrm{I})$ complexes. When the prophylactic experiment was repeated using a concentration dosage of $2 \times \mathrm{MIC}_{100}$ concentration the \% survival of larvae decreased in all cases. Complex 2 still offered the best protection $(65 \%$
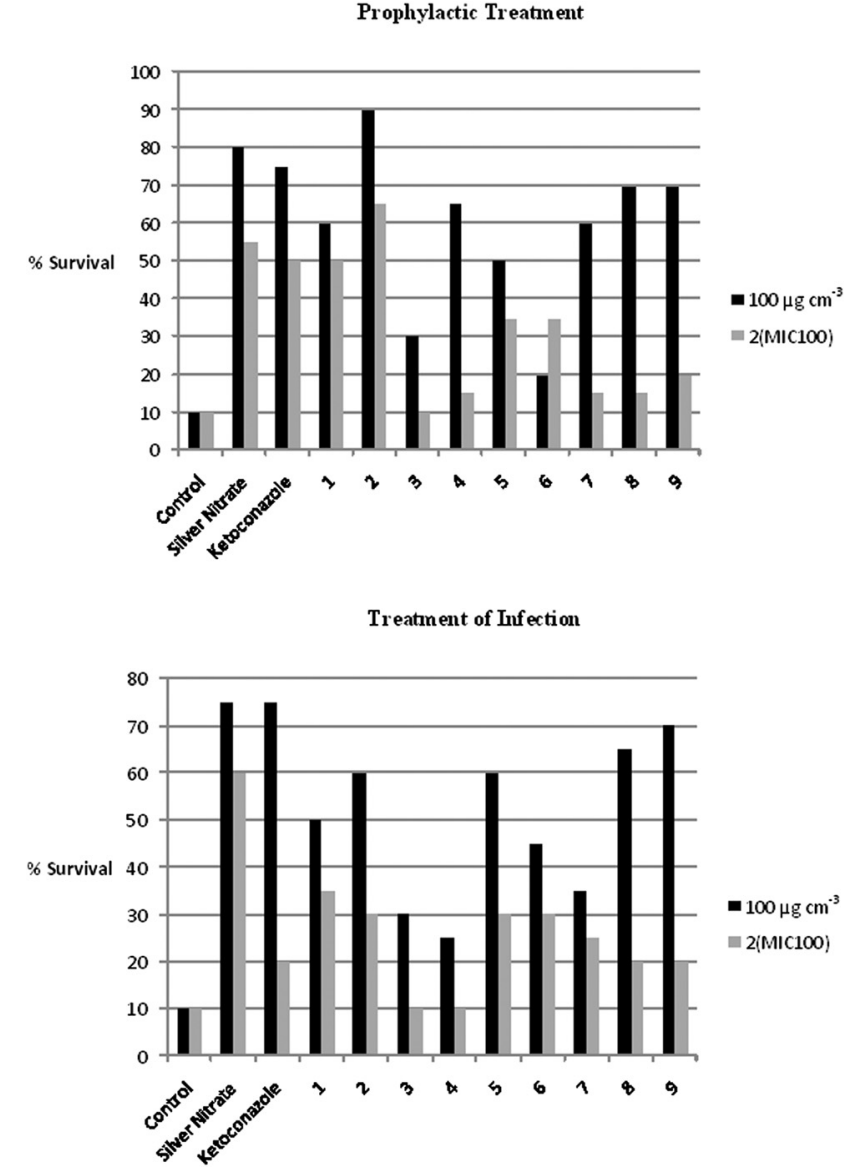

Fig. 12 Survival of G. mellonella larvae $72 \mathrm{~h}$ after being infected with a lethal dose of $C$. albicans $\left(2 \times 10^{6}\right.$ fungal cells $)$. For prophylactic treatment, the test compound was administered $1 \mathrm{~h}$ prior to infection with $C$. albicans cells, while for the treatment of infection experiments the compound was administered $1 \mathrm{~h}$ after infection with C. albicans. Compounds tested were $\mathrm{AgNO}_{3}$, ketoconazole and 1-7. All compounds were administered at two different concentrations $\left(100 \mu \mathrm{g} \mathrm{cm} \mathrm{cm}^{-3}\right.$ and $2 \times$ $\mathrm{MIC}_{100}$ concentration in $\mu \mathrm{g} \mathrm{cm}^{-3}$ ).

survival) and this was followed by $\mathrm{AgNO}_{3}(55 \%)$. Complex 1 and ketoconazole were equally active $(50 \%)$ at this dosage.

Larvae which were pre-infected with a lethal dose of C. albicans cells and then subsequently treated with $100 \mu \mathrm{g} \mathrm{cm}{ }^{-3}$ of the test compounds, responded best to ketoconazole and silver nitrate (both gave $75 \%$ survival after $72 \mathrm{~h}$ ). The most effective $\mathrm{Ag}(\mathrm{I})$ complex was 7 (70\%), followed by $5(60 \%)$ and $2(60 \%)$. At the $2 \times \mathrm{MIC}_{100}$ concentration dosage all of the test materials 
generally offered less protection towards a pre-existing fungal infection than at the $100 \mu \mathrm{g} \mathrm{cm}^{-3}$ concentration level. $\mathrm{AgNO}_{3}$ performed best (60\% survival), followed by 1 (35\%), $2(30 \%)$ and $5(30 \%)$. Under the same conditions, only $20 \%$ of infected larvae survived upon treatment with ketoconazole.

In summary, the prophylactic method of administering the silver(I) complexes proved more effective at increasing the survival rate of $G$. mellonella infected with $C$. albicans. This may be attributed not only to the efficacy of the test compound (direct anti-effect) but also to the anticipated increase in the number of haemocytes, antimicrobial peptides and proteins produced by the innate immune system of the insect in response to the presence of the administered foreign substance (indirect anti-effect). ${ }^{50}$

\section{Conclusions}

A myriad of structurally diverse Ag(I) complexes containing the 9-anthracenecarboxylate anion and imidazoles can be synthesised from the parent complex, $\left[\mathrm{Ag}_{2}(9 \text {-aca })_{2}\right]$ (1). While many of the complexes possess excellent, in vitro antifungal and antibacterial activities they are, unanimously, more effective against fungal cells. G. mellonella can survive high doses of the $\mathrm{Ag}$ (I) complexes administered in vivo, and a number of the complexes offer significant protection to larvae infected with a lethal dose of pathogenic $C$. albicans cells. These silver complexes offer significant potential as new antimicrobial agents for clinical application.

\section{Acknowledgements}

Financial support from the Irish Research Council for Science, Engineering and Technology (IRCSET) and the John and Pat Hume Scholarship Scheme, NUI Maynooth (R. Curran) are gratefully acknowledged.

\section{Notes and references}

1 S. R. Wilkinson and J. M. Kelly, Expert Rev. Mol. Med., 2009, 11, e31.

2 H. S. Fraimow and C. Tsigrelis, Crit. Care Clin., 2011, 27, 163.

3 M. H. Miceli, J. A. Díaz and S. A. Lee, Lancet Infect. Dis., 2011, 11, 142.

4 A. Melaiye and W. J. Youngs, Expert Opin. Ther. Pat., 2005, 15, 125.

5 S. Silver, FEMS Microbiol. Rev., 2003, 27, 341.

6 A. B. G. Lansdown, Crit. Rev. Toxicol., 2007, 37, 237.

7 M. K. Dasgupta, Adv. Perit. Dial., 1994, 10, 195.

8 A. P. Adams, E. M. Santschi and M. A. Mellencamp, Vet. Surg., 1999, 28, 219.

9 W. W. Monafo and B. Freedman, Surg. Clin. North Am., 1987, 67, 133.

10 J. B. Wright, K. Lam and R. E. Burrell, Am. J. Infect. Control, 1998, 26, 572.

11 J. B. Wright, K. Lam, J. Hansen and R. E. Burrell, Am. J. Infect. Control, 1999, 27, 344.

12 J. Jain, S. Arora, J. M. Rajwade, P. Omray, S. Khandelwal and K. M. Paknikar, Mol. Pharmaceutics, 2009, 6, 1388.

13 D. R. Monteiro, L. F. Gorup, A. S. Takamiya, A. C. Ruvollo-Filho, E. Rodrigues de Camargo and D. Barros Barbosa, Int. J. Antimicrob. Agents, 2009, 34, 103.

14 M. McCann, M. Geraghty, M. Devereux, D. O'Shea, J. Mason and L. O'Sullivan, Met.-Based Drugs, 2000, 7, 185.

15 B. Coyle, K. Kavanagh, M. McCann, M. Devereux and M. Geraghty, BioMetals, 2003, 16, 321.

16 B. Coyle, P. Kinsella, M. McCann, M. Devereux, R. O'Connor, M. Clynes and K. Kavanagh, Toxicol. in Vitro, 2004, 18, 63.

17 R. Rowan, M. McCann and K. Kavanagh, Med. Mycol., 2010, 48, 498.
18 S. J. Berners-Price, R. K. Johnson, A. J. Giovenella, L. F. Faucette, C. K. Mirabelli and P. J. Sadler, J. Inorg. Biochem., 1988, 33, 285.

19 K. M. Hindi, A. J. Ditto, M. J. Panzner, D. A. Medvetz, D. S. Han, C. E. Hovis, J. K. Hilliard, J. B. Taylor, Y. H. Yun, C L. Cannon and W. J. Youngs, Biomaterials, 2009, 30, 3771.

20 M.-X. Li, D. Zhang, L.-Z. Zhang and J.-Y. Niu, Inorg. Chem. Commun., 2010, 13, 1268.

21 M. Devereux, M. McCann, D. O' Shea, R. Kelly, D. A. Egan, C. Deegan, K. Kavanagh, V. McKee and G. J. Finn, J. Inorg. Biochem., 2004, 98, 1023.

22 M. McCann, B. Coyle, S. McKay, P. McCormack, K. Kavanagh, M. Devereux, V. McKee, P. Kinsella, R. O'Connor and M. Clynes, BioMetals, 2004, 17, 635.

23 B. Coyle, M. McCann, K. Kavanagh, M. Devereux, V. McKee, N. Kayal, D. A. Egan, C. Deegan and G. J. Finn, J. Inorg. Biochem., 2004, 98, 1361.

24 K. B. Holt and A. J. Bard, Biochemistry, 2005, 44, 13214.

25 H. Wang, N. Law, G. Pearson, B. E. Van Donegen, R. M. Jarvis, R. Goodacre and J. R. Lloyd, J. Bacteriol., 2009, 192, 1143.

26 Q. Feng, J. Biomed. Mater. Res., 2000, 52, 662.

27 W.-K. Jung, H.-C. Koo, K.-W. Kim, S. Shin, S.-H. Kim and Y.-H. Park, Appl. Environ. Microbiol., 2008, 74, 2171.

28 S. L. Percival, P. G. Bowler and D. Russell, J. Hosp. Infect., 2005, 60, 1.

29 S. Y. Liau, D. C. Read, W. J. Pugh, J. R. Furr and A. D. Russell, Lett. Appl. Microbiol., 1997, 25, 279.

30 G. McDonnel and A. D. Russell, Clin. Microbiol. Rev., 1999, 12, 147.

31 A. D. Russell and W. B. Hugo, Prog. Med. Chem., 1994, 31, 351.

32 H. Arkawa and J. F. Neault, Biophys. J., 2001, 81, 1580.

33 H.-J. Park, J. Y. Kim, J. Kim, J.-H. Lee, J.-S. Hahn, M. B. Gu and J. Yoon, Water Res., 2009, 43, 1027.

34 H. Le Pape, F. Solano-Serena, P. Contini, C. Devillers, A. Maftah and P. Leprat, J. Inorg. Biochem., 2004, 98, 1054.

35 R. Curran, J. Lenehan, M. McCann, K. Kavanagh, M. Devereux, D. A. Egan, G. Clifford, K. Keane, B. S. Creaven and V. McKee, Inorg. Chem. Commun., 2007, 10, 1149.

36 G. M. Sheldrick, Acta Crystallogr., Sect. A: Found. Crystallogr., 2007, 64, 112.

37 J. Klein, Scand. J. Immunol., 1997, 46, 558.

38 M. Salzet, Trends Immunol., 2001, 22, 285.

39 J. B. Walters and N. A. Ratcliffe, J. Insect Physiol., 1983, 29, 417.

40 G. Dunphy and A. Halwani, J. Insect Physiol., 1997, 43, 1023.

41 G. B. Dunphy, D. B. Morton, A. Kropinski and J. M. Chadwick, J. Invertebr. Pathol., 1986, 47, 48.

42 K. Kavanagh and E. P. Reeves, FEMS Microbiol. Rev, 2004, 28, 101.

43 J. Renwick, P. Daly, E. P. Reeves and K. Kavanagh, Mycopathologia, 2006, 161, 377.

44 M. Brennan, D. Y. Thomas, M. Whiteway and K. Kavanagh, FEMS Immunol. Med. Microbiol., 2002, 34, 153.

45 D. Bergin, L. Murphy, J. Keenan, M. Clynes and K. Kavanagh, Microbes Infect., 2006, 8, 2105.

46 D. Bergin, E. P. Reeves, J. Renwick, F. B. Wientjes and K. Kavanagh, Infect. Immun., 2005, 73, 4161.

47 P. Mowlds and K. Kavanagh, Mycopathologia, 2007, 165, 5.

48 P. Mowlds, A. Barron and K. Kavanagh, Microbes Infect., 2008, 10, 628.

49 E. Mylonakis, R. Moreno, J. B. El Khoury, A. Idnurm, J. Heitman, S. B. Calderwood, F. M. Ausubel and A. Diener, Infect. Immun., 2005, 73, 3842 .

50 R. Rowan, C. Moran, M. McCann and K. Kavanagh, BioMetals, 2008, 22, 461

51 M. F. Effendy, C. Pettinari, R. Pettinari, A. Pizzablocca, B. W. Skelton and A. H. White, Inorg. Chim. Acta, 2006, 359, 1504.

52 G. W. Eastland, M. A. Mazid, D. R. Russell and M. C. R. Symons, J. Chem. Soc., Dalton Trans., 1980, 1682.

53 Spectroscopic Tools; http://www.science-and-fun.de/tools/

54 Y. Kachkurova, Theor. Exp. Chem., 1967, 3, 498.

55 G. B. Deacon and R. J. Phillips, Coord. Chem. Rev., 1980, 33, 227.

56 P. Pyykkö, Chem. Rev., 1997, 97, 597.

57 C.-S. Liu, P.-Q. Chen, Z. Chang, J.-J. Wang, L.-F. Yan, H.-W. Sun, X.-H. Bu, Z. Lin, Z.-M. Li and S. R. Batten, Inorg. Chem. Commun., $2008, \mathbf{1 1}, 159$.

58 L. J. Ashfield, A. R. Cowley, J. R. Dilworth and P. S. Donnelly, Inorg. Chem., 2004, 43, 4121.

59 A. Castiñeiras, I. García-Santos, S. Dehnen and P. Sevillano, Polyhedron, 2006, 25, 3653.

60 R. Rowan, T. Tallon, A. M. Sheahan, R. Curran, M. McCann, K. Kavanagh, M. Devereux and V. McKee, Polyhedron, 2006, 25, 1771. 